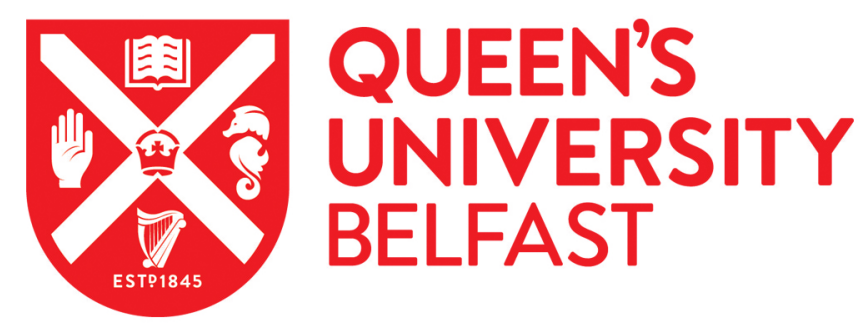

\title{
Understanding the Association between Stunting and Child Development in Low- and Middle-Income Countries: Next Steps for
} Research and Intervention

Perkins, J. M., Rockli, K., Krishna, A., McGovern, M., Aguayo, V. M., \& Subramanian, S. V. (2017).

Understanding the Association between Stunting and Child Development in Low- and Middle-Income Countries: Next Steps for Research and Intervention. Social Science \& Medicine, 193, 101-109.

https://doi.org/10.1016/j.socscimed.2017.09.039

\section{Published in:}

Social Science \& Medicine

Document Version:

Peer reviewed version

Queen's University Belfast - Research Portal:

Link to publication record in Queen's University Belfast Research Portal

\begin{abstract}
Publisher rights
Copyright 2017 Elsevier.

This manuscript is distributed under a Creative Commons Attribution-NonCommercial-NoDerivs License

(https://creativecommons.org/licenses/by-nc-nd/4.0/), which permits distribution and reproduction for non-commercial purposes, provided the author and source are cited.

\section{General rights}

Copyright for the publications made accessible via the Queen's University Belfast Research Portal is retained by the author(s) and / or other copyright owners and it is a condition of accessing these publications that users recognise and abide by the legal requirements associated with these rights.
\end{abstract}

\section{Take down policy}

The Research Portal is Queen's institutional repository that provides access to Queen's research output. Every effort has been made to ensure that content in the Research Portal does not infringe any person's rights, or applicable UK laws. If you discover content in the

Research Portal that you believe breaches copyright or violates any law, please contact openaccess@qub.ac.uk. 
Understanding the association between stunting and child development in low- and middle-income countries: Next steps for research and intervention

\section{September 2017}

\section{Jessica M. Perkins}

Department of Human and Organizational Development, Peabody College of Education and Human Development, Vanderbilt University, Nashville, TN, United States

Vanderbilt Institute of Global Health, Vanderbilt University Medical Center, Nashville, TN, United States

\section{Rockli Kim}

Department of Social and Behavioral Sciences, Harvard T.H. Chan School of Public Health, Boston, MA, United States

\section{Aditi Krishna}

Iris Group, Ottawa, ON, Canada

\section{Mark McGovern}

CHARMS - Centre for Health Research at the Management School, Queen's University Belfast, United Kingdom

UKCRC Centre of Excellence for Public Health (Northern Ireland)

Victor M. Aguayo

United Nations Children's Fund (UNICEF), Programme Division, New York, NY, United States

\section{S.V. Subramanian}

Department of Social and Behavioral Sciences, Harvard T.H. Chan School of Public Health, Boston, MA, United States

Harvard Center for Population and Development Studies, Harvard T.H. Chan School of Public Health, Boston, MA, United States 


\title{
Understanding the association between stunting and child development in low- and middle-income countries: Next steps for research and intervention
}

\begin{abstract}
Stunting, caused by experiences of chronic nutritional deprivation, affects approximately $25 \%$ of children under age five globally (i.e., 156 million children). In this review, evidence of a relationship between stunting and child development in low- and middle-income countries is summarized, and issues for further research are discussed. We focus on studies that measured low height-for-age among children less than 5 years old as the exposure and gross/fine motor skills, psychosocial competencies, cognitive abilities, or schooling and learning milestones as the outcomes. This review highlights three key findings. First, the variability in child development tools and metrics used among studies and the differences in the timing and frequency of the assessments complicate comparisons across study findings. Second, considerable evidence from across many countries supports an association between stunting and poor child development despite methodological differences and heterogeneity in the magnitude of associations. Further, effect sizes differ by developmental domain with greater associations shown for cognitive/ schooling outcomes. How stunting influences child development, which domains of child development are more affected, and how the various domains of child development influence one another require further experimental research to test causal pathways. Finally, there is mixed evidence of the additive effect of nutrition and stimulation interventions on child development. However, understanding best methods for improving child developmental outcomes - either through nutrition programs or through integrated nutrition and psychosocial stimulation programs (or nutrition and other program interventions) - is a key area of further inquiry. Given that nearly $40 \%$ of children under age five suffer from loss of developmental potential - for which stunting is likely one of the key risk factors - reductions in stunting could have tremendous implications for child development and human capital formation, particularly in low- and middle-income countries.
\end{abstract}

Keywords: Child development, Cognition, Stunting, Undernutrition, Gross motor, Fine motor, Psychosocial skills, Cognitive ability, Height

JEL Codes: I10, J10 


\section{Introduction}

The 2015 Sustainable Development Goals (UN, 2015) and several expert reviews on child development call for new research and interventions to prioritize solutions to the global challenge of poor child development in low- and middle-income countries (LMICs) (Black et al., 2016; Britto et al., 2016; Dua et al., 2016; Richter et al., 2016). Child development can generally be defined as the attainment of gross motor and fine motor skills, psychosocial competencies, and cognitive abilities. Although many factors may impact child development, numerous cross-sectional studies and two meta-analyses provide important initial evidence of a link between impaired linear growth and poor child development (Miller et al., 2015; Sudfeld et al., 2015; Walker et al., 2007b, 2011). The behavior of stunted children is often associated with apathy, detachment from social environments, cognitive deficits, poorer learning outcomes and lower educational attainment, as well as reduced economic prospects in the future, thus perpetuating intergenerational transfers of undernutrition and poverty (Alderman et al., 2014; Currie and Vogl, 2013; Grantham-McGregor et al., 2007; Perkins et al., 2016). If stunting causes developmental deficits, then the consequences at the population-level are immense, as there are 156 million children across the world who are stunted (UNICEF et al., 2016).

A meta-analysis of cross-sectional studies found that linear growth among children less than two years old was associated with cognitive and motor development across diverse studies from 29 LMICs (Sudfeld et al., 2015). Similarly, evidence from 15 countries participating in the Multiple Indicator Cluster Surveys showed associations between stunting and some child development domains, though the associations varied by country and other factors (Miller et al., 2015). Drawing a definitive conclusion about these relationships from meta-analyses is difficult, however, given substantial heterogeneity in how studies are conducted, the populations that are targeted, whether it is linear growth or stunting that is measured, and the tools used to measure various child development domains. Challenges with accurately measuring linear growth and stunting may also affect conclusions (Corsi et al., 2017).

In addition, a causal relationship between stunting and child development should not be assumed based on evidence from observational studies due to the potential for many factors, such as socioeconomic status and place, to confound the relationship. For example, stunted children are more likely to grow up in conditions of overall deprivation, which affect both physical growth and child development (GranthamMcGregor et al., 2007). Thus, studies need to adequately account for a variety of confounding factors at various levels of influence.

Taken together, these challenges make it difficult to determine how to use observational evidence about the stunting-child development relationship for intervention purposes, particularly for researchers and policy-makers who may be unfamiliar with this area of work. Moreover, caution is needed when using evidence from meta-analyses for decision-making about further research and intervention development (Ioannidis, 2016).

To address these challenges, several studies have used designs that permit causal assessments of the extent to which linear growth and stunting impact child development. Including these studies' conclusions alongside findings from observational studies that have been reviewed in the past would provide a stronger case for deciding how to invest in programs that target stunting reduction while supporting paths to meet global goals for improving child development. Thus, the purpose of this paper is to provide a substantive review of the association between stunting and child development in LMICs based on evidence from 
correlational designs, quasi-experimental studies, randomized nutrition interventions and nutrition and psychostimulation interventions. This review moves beyond presenting a quantitative summary assessment of the observational relationship between stunting and child development by discussing the current extent of literature on stunting and child development with the objective of understanding the conceptual relationships between stunting as a measure of nutritional deprivation and child development. In addition, we describe challenges associated with measures and study designs as well as with interpretation of results within and across studies.

Finally, we discuss how this area of research may evolve and inform the development of evidence-based intervention programs. Although other determinants of child development are important for policy and intervention (e.g., addressing socioeconomic conditions), we focus here on the direct relationship between stunting and child development. We are motived to offer this review given the considerable interdisciplinary attention on addressing child development and on how nutritional deprivation may play a role in impacting population human capital and wellbeing. This repository of information will be useful for policymakers, practitioners, program managers, or researchers new to this field, who seek to reduce stunting and address child development challenges, particularly in LMICs.

\section{Identifying peer-reviewed evidence on stunting and child development}

We conducted a comprehensive review of key databases in public health, economics, social science, and psychology (PubMed, Web of Science, PsycInfo and Embase) to identify studies on stunting and child development to include in this review. We searched for studies or reviews of studies assessing height (or length) among 0-5 year old children as an exposure for child development. Height could be measured as (a) height-for-age, which is a linear growth measure standardized into z-scores using international growth standards or (b) stunting, which is a widely used binary indicator of chronic undernutrition in infancy and early childhood (WHO, 2006). Stunting occurs when a child's height is more than two standard deviations below the median height-forage among children of a given sex according to WHO Child Growth Standards. We included papers using either or both height measures as they capture different, but related exposures.

We further required studies and reviews to have focused on at least one measure of child development as the outcome. Most child development assessment tools focus on major educational milestones, measure a specific individual developmental domain (e.g., gross motor skills, fine motor skills, or psychosocial development), or use a battery of skills tests. Web Tables 1-3 provide a list of common assessments and the typical targeted population. For a more in-depth discussion on individual child development assessment tools, there are several recent reviews (Fernald et al., 2009b; Frongillo et al., 2014; Sabanathan et al., 2015).

The following search terms were used: cognition, cognitive, awareness, consciousness, cognitive disorder, intelligence, intelligence tests, mental tests, achievement, achievement tests, school readiness, psychosocial, behavior, attitude, height, stunting, stunt, height-for-age, anthropometry, anthropometric, growth, growth disorders, infant, infancy, child, and childhood. Only studies published in English were included. 
As part of this review, we first discuss the many challenges that exist when comparing studies on child development, which make comparisons between results and generalizations difficult. After acknowledging such challenges and caveats, we review evidence of the association between stunting and child development provided by cross-sectional and longitudinal observational studies, as well as from quasi-experimental studies and randomized experiments. After establishing a plausible link between stunting and child development, we then briefly review potential mechanisms through which stunting may lead to developmental impairments. Finally, we highlight gaps in knowledge and further directions for this area of research. We conclude by discussing why the potential for a causal connection between stunting and child development matters for policies, programs, and advocacy.

\section{Challenges with child development assessments}

Most child development assessments were designed for use with English-speaking populations in highincome countries. Thus, challenges arise when using them in LMICs (Grantham-McGregor, 1984, 1993). Although many child development metrics have been adapted for local contexts, they may not be appropriate for children living in poverty and therefore may lead to biased testing results (Isaacs and Oates, 2008; Prado and Dewey, 2014). A study on child development across eight LMICs emphasized that significant effort and time is needed to adapt child development assessment tools, develop and implement standard operating procedures, and ensure high quality data collection across places (Murray-Kolb et al., 2014). Thus it is possible to overcome these particular challenges, but doing so may be time-consuming and expensive.

Instead of using difficult to adapt tests that are also often hard to administer in low-resource settings, studies on child development often evaluate learning and schooling outcomes such as grade completion or years of schooling in lieu of cognitive tests. Although these measures would not always apply to children under age five, the quality of education, the selection of material that is taught, and the amount of learning that occurs during years of education, vary both within and between countries (Behrman and Birdsall, 1983). These factors may not be challenges if studies always selected children from within the same school, but studies often sample children from various locations. In addition, assessment implementation varies in practice. For cognitive assessments, children most often engage in the testing. In contrast, to assess motor and psychosocial development, parents, teachers, or an observer often assess a child's skills. Therefore, children's performance on these assessments is not only a measure of their abilities, but also reflects their interactions with the test administrator and the testing situation (Isaacs and Oates, 2008).

Finally, the use of varied child development tools and metrics across studies as well as differences in assessment timing and frequency complicate comparisons of results (Grantham-McGregor and BakerHenningham, 2005; Sudfeld et al., 2015). Moreover, there are also differences in how test results are analyzed. Some studies use number of successes as measures of cognitive ability (e.g., number of objects correctly identified by children taking the Peabody Picture Vocabulary Test) while others transform the raw numbers of successes into age-standardized z-scores or percentiles (Cheung et al., 2008). Thus, these differences in testing approaches and methodology need to be considered when interpreting findings in the literature. 


\section{Evidence of a link between stunting and child development}

\subsection{Cross-sectional observational studies}

A recent review found that across cross-sectional studies, height-for-age z-scores (HAZ) were positively associated with gross motor scores and odds of walking among children $\leq 2$ years old (Sudfeld et al., 2015). Similarly, HAZ scores were positively associated with multivariate adjusted standardized mean differences in cognitive scores among children 0e23 months old, and, to a lesser extent, among children ages two and older (Sudfeld et al., 2015). Due to differences in how psychosocial developmentwas measured and the small number of studies included, generalized findings about the association between HAZ and psychosocial development could not be established. Detailed information and findings from other cross-sectional studies included in this review are presented inWeb Tables 4A-C (Abubakar et al., 2008; Avan et al., 2010; Bogale et al., 2013; Crookston et al., 2011; Fernald et al., 2006; Handal et al., 2007; Kariger et al., 2005; Ketema et al., 2003; Kordas et al., 2004; Kuklina et al., 2006; Mohd Nasir et al., 2012; Olney et al., 2007, 2009; Siegel et al., 2005; Taneja et al., 2005). Overall, these studies show a positive relationship between child height and child development. There are two critical limitations to cross-sectional studies. First, they only capture the relationship between stunting and child development at one time point. Thus, they are not able to ascertain whether changes in stunting affect changes in development status, nor can they provide any indication as to whether stunting precedes, or occurs in tandem with, poor child development. Second, a third variable may influence both stunting and child development. If such a variable is not included in the analyses, then stunting and child development may appear linked even if they do not share a causal relationship.

\subsection{Longitudinal observational studies}

The same recent review study described above also reported positive prospective associations between $\mathrm{HAZ}$ at 3 years old or younger and gross motor scores at age 5-8 years and also between HAZ at two years old or younger and cognition at age 5-11 years (Sudfeld et al., 2015). In addition, evidence across several studies suggested that stunting was associated with poor psychosocial development among children who were stunted at age 9-24 months. Associations from studies included in this review are shown in Web Tables 5A-C (Adair et al., 2013; Alberto Camargo-Figuera et al., 2014; Aubuchon-Endsley et al., 2011; Aurino and Burchi, 2014; Berkman et al., 2002; Casale et al., 2014; Chang et al., 2002, 2010; Cheung and Ashorn, 2010; Cheung et al., 2001, 2008; Crookston et al., 2013; Gardner et al., 1999; Hamadani et al., 2012, 2014; Kuklina et al., 2004, 2006; Lima et al., 2004; Mendez and Adair,1999; Nguyen et al., 2017; Niehaus et al., 2002; Pollitt et al., 1993; Sanchez, 2013; Walker et al., 2000, 2007a; Whaley et al., 1998; Yang et al., 2011). Most studies indicated an association between stunting or child height and child development across each of the developmental domains. The main limitation of these longitudinal studies is that they still cannot make claims of causality because analyses may not have adequately adjusted for critical confounding variables, such as various indicators of poverty.

\subsection{Quasi-experimental studies}

Quasi-experimental studies have provided some evidence that stunting causes cognitive impairments by using instrumental variables (e.g., rainfall or food price shocks) or natural experiments in the form of social welfare programs (e.g., the Protective Safety Nets Program, the National Rural Employment 
Guarantee Scheme, or similar initiatives), which are not randomly implemented but are plausibly exogenous to stunting and cognitive status. Other quasi-experimental studies use data from siblings to account for unmeasured confounding at the household level. Most of these studies have found negative effects of stunting on cognitive development with varying effect sizes as seen inWeb Table 6 (Dercon and Porter, 2014; Glewwe et al., 2001; Glewwe and King, 2001; Leight et al., 2015; Outes-Leon et al., 2011; Umana-Aponte, 2011).

\subsection{Experimental studies on social welfare}

Some experimental studies assess how program-facilitated changes in nutritional status influence child development by studying the effects of social welfare programs that enroll participants randomly (Web Table 7). Two out of five studies included in this review found that improvements in cognitive development due to cash transfer programs were mediated by increases in height (Fernald et al., 2008, 2009a). In contrast, the other three studies indicated that cash transfers had no effect on height, but independently improved cognition (Fernald and Hidrobo, 2011; Macours et al., 2012; Paxson and Schady, 2010). Follow-up periods in these studies may not have been long enough, however, to observe changes in height or stunting status.

\subsection{Experimental studies on nutrition supplementation}

Four out of eight studies included in this review found improved motor development among children who received nutrition supplementation and only one out of five studies found psychosocial development benefits. In contrast, several studies included in this review found that early nutrition supplementation appeared to influence cognitive development (Web Tables 8A-C) (Chang et al., 2010; Frongillo et al., 2017; Gardner et al., 1999; Grantham- McGregor et al., 1991, 1996, 1997; Nahar et al., 2012; Pollitt et al., 1993, 1995, 1997; Prado et al., 2017; Vazir et al., 2012; Waber et al., 1981; Walker, 2006). However, a recent review of more than 20 studies of nutrition interventions in LMICs found few effects on cognitive development among children under two years (Aboud and Yousafzai, 2015; Larson and Yousafzai, 2017). Although some evidence suggests that supplementation improves developmental outcomes, there is substantial heterogeneity in the design of these studies. Moreover, the effects of supplementation may not be uniform and may instead depend on many factors which nonexperimental studies have been found to be relevant for child development, such as the timing and duration of the intervention (Martorell, 1995; Pollitt et al., 1995), child sex (Martorell, 1995; Waber et al., 1981) and socioeconomic status (Pollitt, 2009; Pollitt et al., 1993, 1995).

\subsection{Interventions integrating nutrition supplementation and stimulation}

As enhancing psychosocial stimulation among children impacts cognitive and language development among children under the age of 2 years in LMICs (Aboud and Yousafzai, 2015), there is a great interest in exploring the synergistic interaction between nutrition supplementation and stimulation on child development more broadly. Comprehensive summaries of existing studies on such integrated programs are provided in recent reviews (Black et al., 2015; Grantham-McGregor et al., 2014). In addition, one paper reviewed the implementation process of integrated nutrition and psychosocial stimulation (Yousafzai and Aboud, 2014) and a more recent study reviewed the benefits and challenges of implementing integrated interventions to address early childhood development and nutrition (Hurley et al., 2016). Of the ten studies reviewed here, three studies found that the combined treatment effects (i.e., 
nutrition supplementation and psychosocial stimulation) were significantly more effective for motor skills and cognitive development than was either treatment alone among children in Bangladesh (Nahar et al., 2012) and Jamaica (Grantham-McGregor et al., 1991). However, the additive effect of combined treatments was no longer significant four years after the end of the study in Jamaica (Grantham-McGregor et al., 1997). A more recent study in Jamaica found significant interactions between zinc supplementation and psychosocial stimulation on the development quotient (Gardner et al., 2005). Other studies found no interaction between the two interventions on stunting and child development (Web Table 9) (Aboud and Akhter, 2011; Chang et al., 2010; Gardner et al., 1999; Vazir et al., 2013; Walker et al., 2007a; Yousafzai et al., 2014).

\subsection{Potential pathways}

The associations between stunting and child development present in some of the papers we reviewed may be due to a variety of different processes linking the exposure and outcome. Although it is a nascent area of work, several studies suggest various mechanistic pathways, including neurological (Black, 1998; John et al., 2017; Lozoff, 2007; Vohr et al., 2017), hormonal (Berger, 2001; Le Roith, 1997; van Pareren et al., 2004), functional isolation (Grantham-McGregor et al., 2007), stress (Fernald and Grantham- McGregor, 1998; Soeters and Schols, 2009; Wachs et al., 2013), stigma (Currie and Vogl, 2013), and infectious disease related channels (Black et al., 2013; UNICEF, 2013; Walker et al., 2007b). The research to date, however, is often unclear on whether such factors act as mediators or as precursors to stunting. In addition, these pathways may dynamically interact with each other. For example, impaired motor development may mediate the relationships between stunting and cognitive development (Larson and Yousafzai, 2017). Stunted children with lower motor activity are more likely to be carried by caregivers, further handicapping motor development and inhibiting cognitive and psychosocial development attained through independent exploration of environments (Adolph et al., 2003; Kariger et al., 2005; Gardner et al., 1995; Olney et al., 2007; Siegel et al., 2005). Greater apathy as well as distress in stunted children (GranthamMcGregor,1995; Pollitt, 2000) increase the likelihood that caregivers treat stunted children as if they were younger, resulting in a lack of age-appropriate stimulation (Kuklina et al., 2004). Taking this evidence together, children's motor, psychosocial, and cognitive development occur in an interactive and dynamic manner with significant influence from their social environments (Wachs et al., 2013). The lack of study designs permitting rigorous mechanistic assessment, however, prohibits a definitive layout of a complete framework for pathways and mediators. Research on these pathways (as well as other potential mechanisms) is still in its early stages. Future work on causal pathways will be of particular interest to policy makers trying to identify and support interventions designed to improve child development.

\subsection{Summary of evidence}

We have reviewed findings from many types of studies examining the relationship between stunting and child development. Comparisons of findings from these studies are complicated by heterogeneity in the timing and frequency of measurement, the types of child development metrics used, and the age and composition of study populations. Moreover, the extent to which causal inference has been addressed varies significantly across studies. To provide credible insights into this relationship, future research needs to adequately adjust for any differences in socioeconomic status between stunted and non-stunted children given the strong link between poverty and stunting and between poverty and cognitive development. 


\section{Further questions about stunting and child development}

\subsection{Timing of nutrition interventions}

Nutrition intervention effects on cognition may be greatest in the first two years of life (Pollitt et al., 1993). This claim is supported by findings from several observational studies (Pongcharoen et al., 2012; Sudfeld et al., 2015). However, it is difficult to draw strong conclusions on this issue, at least in respect to the preand postnatal periods, as some studies have found either no difference in associations between prenatal and postnatal linear growth and cognition (Yang et al., 2011), or that postnatal growth is more salient (Adair et al., 2013; Kuklina et al., 2004). Moreover, brain development continues into adulthood (Thompson and Nelson, 2001), with important periods of growth in adolescence and early adulthood (Isaacs and Oates, 2008; Wachs et al., 2013). Further, growth faltering can still happen after the first two years (Lundeen et al., 2013; Prentice et al., 2013), suggesting that children may also be vulnerable to impaired development later in later life (Crookston et al., 2011).

\subsection{Long-run associations and the role of catch-up growth}

Children who experience developmental impairments due to nutritional deprivation in the first 1000 days may be able to recover later on (Levitsky and Strupp, 1995; Strupp and Levitsky, 1995). A recent crosscountry study suggested that sustained linear growth throughout childhood after early stunting may improve child cognition (Georgiadis et al., 2017). Another study found that linear growth after age 2 was associated with cognitive development at age 15 (partly mediated through education), but not by earlier growth (Teivaanmaki et al., 2017). However, the degree to which associations between early stunting and later cognition are mediated by later growth remains unclear. While some studies find that children who catch-up in growth are able to recover in development (Cheung and Ashorn, 2010; Crookston et al., 2010a, 2010b, 2013; Gandhi et al., 2011; Mendez and Adair, 1999), other work finds that catch-up growth does not help children recover cognitive deficits (Sokolovic et al., 2014). Moreover, there is no conclusive evidence about the best timing for catch-up growth (Cheung and Ashorn, 2010; Gandhi et al., 2011). Further research is required to resolve the ambiguity about critical windows for physical and cognitive development as well as the role of catch-up growth.

\subsection{Differential effects on development domains}

Many of the nutrition studies report improvements in cognitive development but no impact on gross or fine motor development or psychosocial development. Although it is possible that heterogeneous effects exist but differ by domain, current assessments for gross motor development, fine motor development and psychosocial development may not adequately reflect the positive impact of nutrition interventions. Alternatively, there may be ongoing interactions between domains not captured by analyses. Advanced statistical techniques such as structural equation models, which allow for an investigation into interactions between multiple determinants, may help illuminate the pathways by which different developmental domains influence one another and how nutritional status may directly or indirectly influence developmental outcomes. However, even these models cannot easily reveal causal links without appropriate data and strong assumptions about omitted confounders. Thus, rigorous experimental studies are needed to test how nutrition may differentially impact different domains of child development. 


\subsection{Integrating interventions}

Child development occurs in a dynamic fashion in which children's characteristics interact with the social environment to influence their development. Therefore, the impact of integrated interventions may be stronger than any nutrition supplementation alone based on theoretical models (Alderman et al., 2014; Black et al., 2015; Christian et al., 2015; DiGirolamo et al., 2014; Fernandez-Rao et al., 2013; GranthamMcGregor et al., 2014). Although evidence on synergy between nutrition and stimulation interventions is inconsistent and inconclusive, some data support the addition of stimulation to nutrition programs to improve child growth as well as developmental outcomes (Gardner et al., 2005; Grantham-McGregor et al., 1997; Nahar et al., 2012). The absence of any major additive effect on child development outcomes in other studies (Aboud and Akhter, 2011; Chang et al., 2010; Gardner et al., 1999; Vazir et al., 2013; Walker et al., 2007a; Yousafzai et al., 2014) indicates that the scope of integrated interventions should expand beyond the current focus on combining macro- or micronutrient supplementation with psychosocial stimulation, and additionally implement other intervention components such as improved sanitation, hygiene, access to health care, and early learning programs. For example, a recent randomized study has begun to assess the combined impact of child development counseling, nutrition, and maternal mental health messaging on subsequent child development in Pakistan (Khan et al., 2017). Overall, there is a need for comprehensive evaluations of a variety of integrated programs, especially concerning long-term sustainability of benefits.

Despite inconsistent evidence on synergistic interaction between nutrition and stimulation on child development, simultaneous implementation of cross-functional policies and programs at the population level aimed at improving food security, reducing poverty and social inequalities, and improving maternal education has exhibited success in reducing undernutrition in some countries in South East Asia and Latin America (DiGirolamo et al., 2014). In addition, two recent reviews concluded that multi-sectoral approaches and integrated interventions combining nutrition, health, education, child protection, responsive parenting and social protection, are critical for building successful and sustainable interventions that will improve child development and increase human capital (Britto et al., 2016; PerezEscamilla and Moran, 2017).

\section{Discussion}

Stunting and child development are major development foci, which are often studied and targeted as separate issues (Berkman et al., 2002; Casale et al., 2014; Grantham-McGregor et al., 2007). Recent reviews based on observational studies, however, have suggested that there is a positive relationship between linear growth and several domains of child development and that promoting early child nutrition will improve child development (Miller et al., 2015; Sudfeld et al., 2015). Building on that initial body of work, this review presents an updated multi-disciplinary perspective on the relationship between stunting and child development for children under five years of age in LMICs by reviewing evidence from a range of study designs and populations and integrating work across the fields of nutrition, social science and public health. We summarize the current state of the literature for researchers and organizations who are newer to this area of work, and discuss challenges in research measurement and interpretation with a focus on three salient findings. 
First, our critical analysis of studies from across multiple disciplines finds that there is considerable heterogeneity in the methodology used to examine the relationship between child stunting and child development. On the one hand, such heterogeneity makes comparisons of study findings difficult. Any attempt to quantitatively pool current evidence on the association between stunting and child development must be carefully interpreted and the results critically questioned. Creating a harmonized way to measure and evaluate the relationship between stunting and child development would be a helpful solution to this issue. Initiatives such as Young Lives and the Consortium of Health-Orientated Research in Transitioning Societies (COHORTS) have attempted to do so by establishing birth cohorts in different countries (Barnett et al., 2013; Richter et al., 2012). These studies use similar measures and study designs, and assess children at similar intervals.

Findings could be used to provide global, cross-comparative evidence of the links between stunting and child development. Such harmonization, however, is nearly impossible for many of the existing studies. On the other hand, consistent results arising from different studies using heterogeneous measures help to show the relevance of stunting to child developmental domains across diverse populations.

Second, although there is evidence that stunting is plausibly linked to poor developmental outcomes among children despite variability in study design and outcome measures, critical questions remain. For example, which domains of child development are more affected and at what ages? What are the mechanisms linking stunting and development? How do the various domains of child development influence one another in the pathway between stunting and development? Can the effects of stunting be reversed? Such gaps in knowledge necessitate a level of caution before drawing general conclusions about the relationship between stunting and child development. Further research using rigorous study designs will push forward our understanding of these critical questions about the formation of human capital.

Finally, improving multiple aspects of the early life environment that are critical for child development may have synergistic or additive effects. Further research is needed on integrated nutrition programs (e.g., programs addressing nutrition and psychosocial stimulation) to evaluate how they affect child development, particularly in the long run. In addition, efforts to improve gross motor and fine motor development, cognition, and psychosocial development should not necessarily be limited to the narrow period of pre- and early-postnatal life. Much remains uncertain and unknown about what happens beyond this period, particularly surrounding the potential for, and consequences of, catch-up growth. Thus, there may be opportunities to intervene on the stunting-child development relationship at later ages. In summary, the complex relationship between stunting and different child development domains presents critical opportunities for testing and scaling up proven interventions to target multiple, interacting factors during childhood.

Questions remain about how markers of linear growth/stunting and child development are used. The literature tends to think of one (i.e., height) (Perkins et al., 2016) as an exposure and another (i.e., child development) as an outcome (Walker et al., 2011). However, child development is a process that incorporates multiple domains, which may co-occur or influence each other. Further, child development is both a function of physical inputs partially captured by anthropometry and other markers, and a function of stimulation independent of any physical factors, with the plasticity of the brain being particularly important. In addition, both linear growth and child development are influenced by a common set of factors. Thus, to a certain extent, the association between linear growth and child development could 
reflect co-varying variables as opposed to one being a cause of the other. Finally, if height is an exposure by itself for child development, then the mechanistic pathways remain understudied.

Across the world, international organizations, national governments and non-governmental organizations recognize the importance of reducing the global burden of stunting on child health and wellbeing. Further, the Sustainable Development Goals endorsed the World Health Assembly's target of reducing the number of stunted children globally by $40 \%$ by 2025 (UN, 2015). In addition to this focus on prevention, it is also important to think about the children who are already stunted and who may be at risk of, or are already experiencing, poor development in at least one domain. What is the modifiable quantity of interest in relation to stunting and child development if much of stunting cannot be reversed? The more than 156 million children who are already stunted should not be forgotten in research or by intervention targets. Instead, the field needs to think in terms of a variety of interventions, ranging from nutrition interventions that target improvements in cognition (and include anthropometric indicators as measurable outcomes) to direct stimulation interventions to some combination of interventions. Moreover, if interventions are able to address the etiologies of stunting and other determinants of poor child development (e.g., poor child stimulation or poverty) simultaneously, they are likely to be more effective in addressing developmental deficits in young children compared to child development interventions focusing solely on educational outcomes, for example.

\section{Conclusion}

Although the literature provides support for the impact of stunting on cognitive development, schooling and learning outcomes, the evidence on whether stunting leads to deficits in motor and psychosocial development is variable. The considerable heterogeneity across research studies in study design, targeted populations, assessment tools, and outcome measures, may be responsible, at least in part, for producing this variability in results. Further testing of the specific mechanisms by which stunting may influence child development and the ways in which various domains of child development influence one another is needed. Randomized controlled trials with multifactorial designs that allow for the testing of both singular and additive effects of different intervention components would help to draw more definitive conclusions about the impact of stunting and nutrition on child development. Given that nearly $40 \%$ of children under age five suffer from loss of developmental potential, for which stunting is one of the key risk factors, reductions in stunting could have tremendous implications for child development and human capital formation, particularly in LMICs. Programs targeting child development for children who are already stunted should also be a focus of ongoing research and intervention. 
Web Table 1. Child development: measures of gross motor and fine motor skills.

\begin{tabular}{lll}
\hline Measure & Domains & $\begin{array}{l}\text { Age of } \\
\text { administration }\end{array}$ \\
\hline Beery scale & Visual-motor integration & $2-18$ years \\
Lafayette Grooved Pegboard Test & Fine motor skills & $5-18$ years \\
$\begin{array}{l}\text { Bruninks-Oseretsky Test of Motor } \\
\text { Proficiency }\end{array}$ & Fine motor skills & $4-18$ years \\
$\begin{array}{l}\text { Neurological Examination of Soft } \\
\text { Signs }\end{array}$ & Hyperactivity, Attention Deficit Hyperactivity Disorder & $5-18$ years \\
Edinburgh Handedness Inventory & Handedness & $3-12$ years \\
Gardner Steadiness Test & $\begin{array}{l}\text { Hyperactivity, attention deficits, motor persistence, } \\
\text { motor coordination }\end{array}$ & $4-18$ years \\
Purdue Pegboard & Dexterity, bimanual coordination & $5-18$ years \\
Kilifi Developmental Inventory & Locomotor skills, eye-hand coordination & 6-35 months \\
Movement Assessment Battery & Motor impairment & $3-16$ years \\
\hline
\end{tabular}


Web Table 2. Child development: psychosocial measures.

\begin{tabular}{|c|c|c|c|}
\hline Measure & Domains & Age of administration & Administered to \\
\hline $\begin{array}{l}\text { Brazelton Neonatal Behavioral Assessment } \\
\text { Scale }\end{array}$ & Behavior, reflex & 0-2 months & Child \\
\hline Rutter Teacher and Parent Scales & $\begin{array}{l}\text { Conduct difficulties, emotional difficulties, hyperactivity/inattention, } \\
\text { prosocial behavior }\end{array}$ & 11-12 years & Parent, teacher \\
\hline How I Think about Myself questionnaire & Self-esteem & 11-12 years onwards & Child \\
\hline $\begin{array}{l}\text { Manifest Anxiety (What I Think and Feel) } \\
\text { Questionnaire }\end{array}$ & Anxiety & 6-19 years & Child \\
\hline Mood and Feelings Questionnaire & Depressive symptoms & $8-18$ years & Child, parent \\
\hline Behavior and Activities Checklist & Antisocial behavior & & Child \\
\hline Conners' Parent Rating Scale & Cognitive problems/inattention, hyperactivity, oppositional behavior & $6-18$ years & Parent \\
\hline Conners' Teacher Rating Scale & Cognitive problems/inattention, hyperactivity, oppositional behavior & 6-18 years & Teacher \\
\hline Richman Child Behavior Scale & $\begin{array}{l}\text { Behavioral difficulties (eating problems, sleep disturbance, soiling, } \\
\text { hyperactivity, lack of concentration, poor relationships, tempers, and } \\
\text { fears) }\end{array}$ & 3 years & Parent \\
\hline Child Behavior Checklist & Children's competencies and problem behaviors & 4-16 years & Parent \\
\hline Strengths and Difficulties Questionnaire & $\begin{array}{l}\text { Hyperactivity, conduct problems, emotional symptoms, peer problems } \\
\text { and prosocial behavior }\end{array}$ & 3-16 years & Child \\
\hline $\begin{array}{l}\text { Brazelton Neonatal Behavioral Assessment } \\
\text { Scale }\end{array}$ & Behavior, reflex & $0-2$ months & Child \\
\hline Rutter Teacher and Parent Scales & $\begin{array}{l}\text { Conduct difficulties, emotional difficulties, hyperactivity/inattention, } \\
\text { prosocial behavior }\end{array}$ & 11-12 years & Parent, teacher \\
\hline How I Think about Myself questionnaire & Self-esteem & 11-12 years onwards & Child \\
\hline $\begin{array}{l}\text { Manifest Anxiety (What I Think and Feel) } \\
\text { Questionnaire }\end{array}$ & Anxiety & 6-19 years & Child \\
\hline Mood and Feelings Questionnaire & Depressive symptoms & $8-18$ years & Child, parent \\
\hline
\end{tabular}




\section{Web Table 3. Child development: cognitive tests and measures of learning/schooling outcomes}

\begin{tabular}{|c|c|c|}
\hline Measure & Domains & Age of administration \\
\hline \multicolumn{3}{|l|}{ Individual cognitive domains } \\
\hline Peabody Picture Vocabulary Test (4th ed) & Language comprehension & 2 years + \\
\hline Stroop test & $\begin{array}{l}\text { Processing speed, attention and executive function, working memory, and cognitive } \\
\text { development }\end{array}$ & 2 years + \\
\hline \multicolumn{3}{|l|}{ Multiple cognitive domains } \\
\hline NEPSY (2nd ed) & $\begin{array}{l}\text { Attention and executive functions, language and communication, sensorimotor, } \\
\text { visuospatial, learning and memory, and social perception }\end{array}$ & $12-16$ years \\
\hline Ages and Stages Questionnaire (3rd ed) & Communication, Gross motor, Fine motor, Problem-solving and Personal-social & $1-66$ months \\
\hline Woodcock-Johnson (3rd ed) & Fluid intelligence, knowledge and comprehension, and processing speed & 2 years + \\
\hline \multicolumn{3}{|l|}{ Overall ability } \\
\hline Bayley Scales of Infant Development (3rd ed) & $\begin{array}{l}\text { Motor (fine and gross), language (receptive and expressive), cognitive, social-emotional, } \\
\text { and adaptive behavior }\end{array}$ & $1-42$ months \\
\hline Griffith's Mental Development Scales & Development quotient & $0-8$ years \\
\hline $\begin{array}{l}\text { Wechsler Intelligence Scales for Children - } \\
\text { Revised (4th ed) }\end{array}$ & Verbal comprehension, perceptual reasoning, working memory, processing speed. & $6-16$ years \\
\hline $\begin{array}{l}\text { Wechsler Preschool and Primary Scale of } \\
\text { Intelligence }\end{array}$ & Verbal skills, cognitive performance, processing speed, and general language & 3-7 years \\
\hline Kaufman's Assessment Battery for Children & Simultaneous processing, sequential, planning, learning, and knowledge & $3-18$ years \\
\hline Ravens Progressive Matrices & Visual reasoning ability & 6 months-17 years \\
\hline Stanford Binet & $\begin{array}{l}\text { Fluid reasoning, knowledge, quantitative reasoning, visual-spatial processing, and working } \\
\text { memory }\end{array}$ & 2 years + \\
\hline British Ability Scales (3rd ed) & $\begin{array}{l}\text { Verbal ability, non-verbal reasoning ability, spatial ability, and diagnostic scales for other } \\
\text { cognitive functions }\end{array}$ & 3-17 years \\
\hline
\end{tabular}


Tests for learning outcomes

Test of Early Mathematical Ability (3rd ed)

Suffolk Reading Scales

Early Grade Reading Assessment

Wide Range Achievement Test
Mathematics

Reading comprehension

Basic skills for literacy acquisition in early grades including prereading skills such as listening comprehension

Arithmetic, spelling, and word reading
3-18 years

6 months-17 years

6-9 years

$5+$ years 


\section{Web Table 4A. Cross-Sectional Studies on Stunting and Gross Motor and Fine Motor Child Development}

\begin{tabular}{|c|c|c|c|c|c|c|c|}
\hline Citation & Country & Findings & $\begin{array}{l}\text { Age of } \\
\text { assessment }\end{array}$ & Measures & $\begin{array}{l}\text { Adjusted } \\
\text { for birth } \\
\text { weight? }\end{array}$ & $\begin{array}{l}\text { Adjusted } \\
\text { for } \\
\text { parental } \\
\text { height? }\end{array}$ & $\begin{array}{l}\text { Adjusted for } \\
\text { parental } \\
\text { education/IQ? }\end{array}$ \\
\hline $\begin{array}{l}\text { (Abubakar et al., } \\
\text { 2008) }\end{array}$ & Kenya & $\begin{array}{l}\text { Correlation between HAZ and psychomotor scores } \\
\text { was } 0.29 \text { (p-value }<0.01) \text {. }\end{array}$ & 24-35 months & Kilifi Developmental Inventory & No & No & $\begin{array}{l}\text { Yes (maternal } \\
\text { education) }\end{array}$ \\
\hline $\begin{array}{l}\text { (Kariger et al., } \\
2005)\end{array}$ & Zanzibar & $\begin{array}{l}\text { 1-SD increase in HAZ was associated with an odds } \\
\text { ratio of } 1.31 \text { ( } 95 \% \text { CI: } 0.90,1.90 ; p=0.127) \text { for } \\
\text { crawling alone and } 2.10(95 \% \text { CI: } 1.68,2.63 \text {; } \\
\text { p }<0.001) \text { for walking alone }\end{array}$ & 1-18 months & $\begin{array}{l}\text { Crawling (for } 1-6 \text { moths); } \\
\text { Walking (for } 6-18 \text { months); } \\
\text { Milestone attainment ( } 14 \text { motor } \\
\text { activities) for all }\end{array}$ & No & No & $\begin{array}{l}\text { Yes (parental } \\
\text { education) }\end{array}$ \\
\hline $\begin{array}{l}\text { (Olney et al., } \\
\text { 2009) }\end{array}$ & Zanzibar & $\begin{array}{l}\text { Correlations between LAZ and motor development: } \\
\text { At } 5-9 \text { months }-0.12(\mathrm{p}=0.026) \text {; At } 10-14 \text { months - } \\
0.30(\mathrm{p}<0.001) \text {; At } 15-19 \text { months - } 0.41(\mathrm{p}<0.001) \text {. } \\
\text { Correlations between LAZ and motor activity: At } 5 \text { - } \\
9 \text { months - } 0.28(\mathrm{p}<0.001) \text {; At } 10-14 \text { months }-0.26 \\
(\mathrm{p}<0.001) \text {; At } 15-19 \text { months }-0.43(\mathrm{p}<0.001) \text {. }\end{array}$ & 5-19 months & $\begin{array}{l}20 \text { motor activities and } 14 \\
\text { motor milestones }\end{array}$ & No & No & No \\
\hline $\begin{array}{l}\text { (Olney et al., } \\
\text { 2007) }\end{array}$ & Zanzibar & $\begin{array}{l}\text { 1-SD change in LAZ was associated with a } 0.034 \\
\text { increase in total motor activity score }(\mathrm{p}<0.001) \text { and } \\
0.65 \text { percentage point increase in the percent of time } \\
\text { spent in locomotion }(\mathrm{p}=0.003) \text {. }\end{array}$ & 5-19 months & $\begin{array}{l}20 \text { motor activities and } 14 \\
\text { motor milestones }\end{array}$ & No & No & $\begin{array}{l}\text { Yes (parental } \\
\text { education) }\end{array}$ \\
\hline $\begin{array}{l}\text { (Siegel et al., } \\
2005)\end{array}$ & Nepal & $\begin{array}{l}\text { 1-SD increase in } \mathrm{LAZ} \text { was associated with a } 1.69 \\
\text { higher odds }(\mathrm{p}<0.01) \text { of walking. }\end{array}$ & 8-17 months & Walking & No & No & No \\
\hline $\begin{array}{l}\text { (Taneja et al., } \\
\text { 2005) }\end{array}$ & India & $\begin{array}{l}\text { 1-SD increase in HAZ was associated with a } 4.09 \\
\text { unit (95\% CI: 3.02, 5.14; } \mathrm{p}<0.001) \text { increase in PDI } \\
\text { score. }\end{array}$ & $12-18$ months & BSID II (PDI) & No & No & $\begin{array}{l}\text { Yes (maternal } \\
\text { education) }\end{array}$ \\
\hline
\end{tabular}

Abbreviations: BSID: Bayley Scales of Infant Development. HAZ: height for age z-score. CI: confidence interval. DQ: Development quotient. IQ: Intelligence quotient. LAZ: length for age z-score. PDI: psychomotor development index. SD: Standard deviation. SE: Standard error. 
Web Table 4B. Cross-Sectional Studies on Stunting and Psychosocial Child Development

\begin{tabular}{|c|c|c|c|c|c|c|c|}
\hline Citation & Country & Findings & $\begin{array}{l}\text { Age of } \\
\text { assessment }\end{array}$ & Measures & $\begin{array}{l}\text { Adjusted for } \\
\text { birth weight? }\end{array}$ & $\begin{array}{l}\text { Adjusted for } \\
\text { parental } \\
\text { height? }\end{array}$ & $\begin{array}{l}\text { Adjusted for } \\
\text { parental } \\
\text { education/IQ? }\end{array}$ \\
\hline $\begin{array}{l}\text { (Avan et al., } \\
\text { 2010) }\end{array}$ & $\begin{array}{l}\text { South } \\
\text { Africa }\end{array}$ & $\begin{array}{l}\text { Stunted children had a mean Richman score of } 3.23 \\
\text { (SD: } 2.11) \text { while non-stunted children had a mean score } \\
\text { of } 2.80(1.99)(\mathrm{p}=0.039) \text {. (High = Better })\end{array}$ & 2 years & $\begin{array}{l}\text { Richman Child } \\
\text { Behavior Scale }\end{array}$ & No & No & $\begin{array}{l}\text { Yes (maternal } \\
\text { education) }\end{array}$ \\
\hline $\begin{array}{l}\text { (Handal et al., } \\
\text { 2007) }\end{array}$ & Ecuador & $\begin{array}{l}\text { At age 3-23 months, there were no significant } \\
\text { differences in mean ASQ scores. At age } 24-61 \text { months, } \\
\text { the mean ASQ problem-solving score among stunted } \\
\text { children was } 30.7 \text { (SD: } 13.3 \text { ) and among non-stunted } \\
\text { children was } 34.1 \text { (SD: } 14.4 \text { ). }\end{array}$ & 3-61 months & ASQ & $\begin{array}{l}\text { Yes (low birth } \\
\text { weight) }\end{array}$ & No & $\begin{array}{l}\text { Yes (parental } \\
\text { education) }\end{array}$ \\
\hline
\end{tabular}

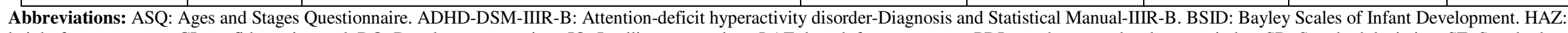
height for age z-score. CI: confidence interval. DQ: Development quotient. IQ: Intelligence quotient. LAZ: length for age z-score. PDI: psychomotor development index. SD: Standard deviation. SE: Standard error. 
Web Table 4C. Cross-Sectional Studies on Stunting and Cognitive Child Development or Learning/Schooling Milestones

\begin{tabular}{|c|c|c|c|c|c|c|c|}
\hline Citation & Country & Findings & $\begin{array}{l}\text { Age of } \\
\text { assessment }\end{array}$ & Measure & $\begin{array}{l}\text { Adjusted for } \\
\text { birth weight? }\end{array}$ & $\begin{array}{l}\text { Adjusted } \\
\text { for parental } \\
\text { height? }\end{array}$ & $\begin{array}{l}\text { Adjusted for } \\
\text { parental } \\
\text { education/IQ? }\end{array}$ \\
\hline $\begin{array}{l}\text { (Ketema et al., } \\
\text { 2003) }\end{array}$ & Ethiopia & $\begin{array}{l}\text { 1-unit increase in HAZ was significantly associated } \\
\text { with increases cognitive } \mathrm{z} \text { score by } 0.296(\mathrm{p}<0.001) \text {. }\end{array}$ & 6-42 months & BSID-II & No & No & No \\
\hline $\begin{array}{l}\text { (Kuklina et al., } \\
\text { 2006) }\end{array}$ & Guatemala & $\begin{array}{l}\text { 1-SD increase in HAZ was associated with } 1.71 \text { unit } \\
\text { (95\% CI: } 1.00 \text { to } 2.43 \text { ) increase in MDI for } 6 \\
\text { months, } 2.82 \text { unit ( } 95 \% \text { CI: } 1.67 \text { to } 3.98 \text { ) increase for } \\
24 \text { months, and } 1.82 \text { unit ( } 95 \% \text { CI, } 0.88 \text { to } 2.75 \text { ) } \\
\text { increase for } 36 \text { months }\end{array}$ & $\begin{array}{l}6,24,36 \\
\text { months }\end{array}$ & BSID-II & $\begin{array}{l}\text { Yes } \\
\text { (gestational } \\
\text { age) }\end{array}$ & No & $\begin{array}{l}\text { Yes (maternal } \\
\text { education) }\end{array}$ \\
\hline $\begin{array}{l}\text { (Taneja et al., } \\
\text { 2005) }\end{array}$ & India & $\begin{array}{l}\text { 1-SD increase in HAZ was associated with a } 1.82 \\
\text { unit (95\% CI: } 1.01 \text { to } 2.63 \text { ) increase in MDI score. }\end{array}$ & $12-18$ months & BSID-II & No & No & $\begin{array}{l}\text { Yes (maternal } \\
\text { education) }\end{array}$ \\
\hline $\begin{array}{l}\text { (Bogale et al., } \\
\text { 2013) }\end{array}$ & Ethiopia & $\begin{array}{l}\text { Correlation between HAZ and working memory was } \\
0.426(\mathrm{p}<0.001) \text { and for visual processing it was } \\
0.422(\mathrm{p}<0.001)\end{array}$ & 5 years & KABC-III & No & No & $\begin{array}{l}\text { Yes (maternal } \\
\text { education only } \\
\text { for visual } \\
\text { processing) }\end{array}$ \\
\hline $\begin{array}{l}\text { (Crookston et } \\
\text { al., 2011) }\end{array}$ & Peru & $\begin{array}{l}\text { 1-SD increase in HAZ was associated with } 0.03 \\
\text { point ( } 95 \% \text { CI: }-0.09 \text { to } 0.14 \text { ) increase in CDA score } \\
\text { for 6-18 months, and } 0.15 \text { point ( } 95 \% \text { CI: } 0.02 \text { to } \\
0.28 \text { ) increase in CDA for } 4-5 \text { years. } \\
\text { For PPVT, } 1 \text {-SD increase in HAZ associated with } \\
0.20 \text { point ( } 95 \% \text { CI: }-0.59 \text { to } 0.99 \text { ) and } 2.23 \text { point } \\
\text { (95\% CI: } 1.29 \text { to } 3.17 \text { ) increases in cognition at ages } \\
6-18 \text { months and } 4-5 \text { years, respectively. }\end{array}$ & $\begin{array}{l}6-18 \text { months, } \\
4-5 \text { years }\end{array}$ & $\begin{array}{l}\text { PPVT, Cognitive } \\
\text { Development } \\
\text { Assessment }\end{array}$ & No & No & $\begin{array}{l}\text { Yes (maternal } \\
\text { education) }\end{array}$ \\
\hline $\begin{array}{l}\text { (Mohd Nasir et } \\
\text { al., 2012) }\end{array}$ & Malaysia & $\begin{array}{l}\text { 1-SD increase in HAZ was associated with } 1.43 \\
\text { increase in RCPM score }(\mathrm{p}<0.001) .\end{array}$ & $\begin{array}{l}\text { 4-6 years } \\
(72.5 \% \text { were } 4-5 \\
\text { years })\end{array}$ & RCPM & No & No & $\begin{array}{l}\text { Yes (maternal } \\
\text { and paternal } \\
\text { education) }\end{array}$ \\
\hline $\begin{array}{l}\text { (Fernald et al., } \\
\text { 2006) }\end{array}$ & Mexico & $\begin{array}{l}\text { Both HAZ and age-adjusted MDI score declined } \\
\text { across the second year of life. Scores were also } \\
\text { lower than US standards for older children, even } \\
\text { after controlling for socio-economic status and } \\
\text { parental characteristics. At } 13-14 \text { months, } 3 \% \text { of } \\
\text { children received less than } 2 \text { SD below median MDI } \\
\text { scores. By } 19-20 \text { months, nearly } 17 \% \text { of children } \\
\text { were } 2 \text { SD or more below. The association between } \\
\text { HAZ and MDI was not tested. }\end{array}$ & $1-2$ years & BSID-II & No & No & $\begin{array}{l}\text { Yes (maternal } \\
\text { and paternal } \\
\text { education) }\end{array}$ \\
\hline
\end{tabular}

Abbreviations: BSID: Bayley Scales of Infant Development ( $2^{\text {nd }}$ version). CAT: Cognitive Abilities Test. HAZ: height for age z-score. CI: confidence interval. DQ: Development quotient. IQ: Intelligence

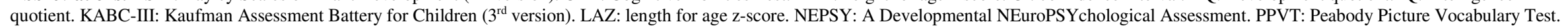
RPM: Raven's Progressive Matrices. RCPM: Raven's Colored Progressive Matrices. SD: Standard deviation. SE: Standard error. MDI: Mental development index 
Web Table 5A. Longitudinal Studies on Stunting and Gross Motor and Fine Motor Child Development

\begin{tabular}{|c|c|c|c|c|c|c|c|c|}
\hline Citation & Country & Findings & $\begin{array}{l}\text { Age } \\
\text { stunting } \\
\text { assessed }\end{array}$ & $\begin{array}{l}\text { Age } \\
\text { outcome } \\
\text { assessed }\end{array}$ & Measures & $\begin{array}{l}\text { Adjusted } \\
\text { for birth } \\
\text { weight? }\end{array}$ & $\begin{array}{l}\text { Adjusted } \\
\text { for } \\
\text { parental } \\
\text { height? }\end{array}$ & $\begin{array}{l}\text { Adjusted for } \\
\text { parental } \\
\text { education/IQ? }\end{array}$ \\
\hline $\begin{array}{l}\text { (Susan M } \\
\text { Chang et al., } \\
\text { 2010) }\end{array}$ & Jamaica & $\begin{array}{l}\text { RSCM scores were lower in the stunted group than } \\
\text { in the non-stunted group }(\mathrm{p}=0.01) \text {, but differences in } \\
\text { dexterity were not significant }(\mathrm{p}=0.18) \text { after } \\
\text { adjusting for social background. Among stunted } \\
\text { children, the RSCM score was significantly } \\
\text { associated with IQ }(\mathrm{p}=0.04) \text { and school achievement } \\
\text { (all } \mathrm{p}<0.05) \text {. }\end{array}$ & $\begin{array}{l}9-24 \\
\text { months }\end{array}$ & $\begin{array}{l}11-12 \\
\text { years }\end{array}$ & $\begin{array}{l}\text { Grooved Pegboard, } \\
\text { Bruininks-Oseretsky } \\
\text { Test of Motor } \\
\text { Proficiency, } \\
\text { Neurological } \\
\text { Examination of Soft } \\
\text { Signs, Finger tap }\end{array}$ & No & No & $\begin{array}{l}\text { Yes (maternal } \\
\text { education and } \\
\text { IQ using PPVT) }\end{array}$ \\
\hline $\begin{array}{l}\text { (Cheung et al., } \\
\text { 2001) }\end{array}$ & Pakistan & $\begin{array}{l}\text { Correlation between HAZ and age at walking was - } \\
0.12(\mathrm{p}<0.05) \text {. Stunting was inversely associated } \\
\text { with age at which independent walking started (Time } \\
\text { ratio=0.96; }<<0.05)\end{array}$ & At birth & $\begin{array}{l}0-6 \\
\text { months }\end{array}$ & $\begin{array}{l}\text { Denver } \\
\text { Developmental } \\
\text { Screening }\end{array}$ & $\begin{array}{l}\text { Yes (birth } \\
\text { weight/ } \\
\text { length) }\end{array}$ & No & $\begin{array}{l}\text { Yes (maternal } \\
\text { education) }\end{array}$ \\
\hline $\begin{array}{l}\text { (Cheung et al., } \\
\text { 2008) }\end{array}$ & Malawi & $\begin{array}{l}\text { 1-SD increase in HAZ was associated with } 0.28 \mathrm{z}- \\
\text { score increase in both gross motor and fine motor } \\
(\mathrm{p}<0.01) \text {. }\end{array}$ & $\begin{array}{l}36 \\
\text { months }\end{array}$ & 3-6 years & $\begin{array}{l}\text { Test of } \\
\text { developmental } \\
\text { milestones }\end{array}$ & No & No & No \\
\hline $\begin{array}{l}\text { (Hamadani et } \\
\text { al., 2012) }\end{array}$ & Bangladesh & $\begin{array}{l}\text { Correlation between HAZ at } 15 \text { months and: Sits } \\
\text { alone: }-0.18(\mathrm{p}<0.01) \text {; Pulls self to stand: }-0.15(\mathrm{p} \\
<0.01) \text {; Stands assisted: }-0.18(\mathrm{p}<0.01) \text {; Walks } \\
\text { assisted: }-0.22(\mathrm{p}<0.01) \text {; Stands alone: }-0.25 \\
(\mathrm{p}<0.01) \text {; Walks alone: }-0.27(\mathrm{p}<0.01) \text {. }\end{array}$ & $\begin{array}{l}3-15 \\
\text { months }\end{array}$ & $\begin{array}{l}18,64 \\
\text { months }\end{array}$ & BSID-II (PDI) & $\begin{array}{l}\text { Yes } \\
\text { (gestational } \\
\text { age) }\end{array}$ & No & $\begin{array}{l}\text { Yes (parental } \\
\text { education) }\end{array}$ \\
\hline $\begin{array}{l}\text { (Kuklina et al., } \\
\text { 2004) }\end{array}$ & Guatemala & $\begin{array}{l}\text { 1-SD increase in HAZ during the first year of life } \\
\text { was associated with a } 0.57 \text { year (SE: } 0.27) \text { earlier } \\
\text { age of walking }(p<0.05) \text {. }\end{array}$ & $\begin{array}{l}1-15 \\
\text { months }\end{array}$ & $\begin{array}{l}10-24 \\
\text { months }\end{array}$ & $\begin{array}{l}\text { 17-milestone Gross } \\
\text { Motor Development } \\
\text { Scale, Walking }\end{array}$ & $\begin{array}{l}\text { Yes (birth } \\
\text { size) }\end{array}$ & No & $\begin{array}{l}\text { Yes (maternal } \\
\text { education) }\end{array}$ \\
\hline $\begin{array}{l}\text { (Kuklina et al., } \\
\text { 2006) }\end{array}$ & Guatemala & $\begin{array}{l}\text { 1-SD increase in HAZ was associated with a } 2.94 \\
\text { unit ( } 95 \% \text { CI: } 1.12,4.76) \text { increase in PDI for } 0-6 \\
\text { months; } 5.5 \text { ( } 95 \% \text { CI: } 3.13,6.97) \text { for } 0-24 \text { months; } \\
\text { and } 5.04 \text { (95\% CI: } 2.52,7.57 \text { ) for } 6-24 \text { months. }\end{array}$ & $\begin{array}{l}\text { 6-36 } \\
\text { months }\end{array}$ & $\begin{array}{l}6-36 \\
\text { months }\end{array}$ & BSID-II (PDI) & $\begin{array}{l}\text { Yes } \\
\text { (gestational } \\
\text { age) }\end{array}$ & No & $\begin{array}{l}\text { Yes (maternal } \\
\text { education) }\end{array}$ \\
\hline $\begin{array}{l}\text { (Lima et al., } \\
\text { 2004) }\end{array}$ & Brazil & $\begin{array}{l}\text { Children with } \mathrm{HAZ}<-1 \text { had mean PDI score of } \\
101.1 \text { while those with } \mathrm{HAZ} \geq-1 \text { had mean PDI } \\
\text { score of } 106.2(\mathrm{p}<0.001) .\end{array}$ & $\begin{array}{l}\text { From } \\
\text { birth }\end{array}$ & $\begin{array}{l}12 \\
\text { months }\end{array}$ & BSID-I (PDI) & $\begin{array}{l}\text { Yes (birth } \\
\text { weight) }\end{array}$ & No & $\begin{array}{l}\text { Yes (maternal } \\
\text { education) }\end{array}$ \\
\hline
\end{tabular}

Abbreviations: BSID: Bayley Scales of Infant Development. HAZ: height for age z-score. CI: confidence interval. DQ: Development quotient. IQ: Intelligence quotient. PDI: psychomotor development index. RSCM: rapid sequential continuous movements. SD: Standard deviation. SE: Standard error. PPVT: Peabody Picture Vocabulary Test. 
Web Table 5B. Longitudinal Studies on Stunting and Psychosocial Child Development

\begin{tabular}{|c|c|c|c|c|c|c|c|c|c|}
\hline Citation & Country & Findings & $\begin{array}{l}\text { Age } \\
\text { stunting } \\
\text { assessed } \\
\end{array}$ & $\begin{array}{l}\text { Age } \\
\text { outcome } \\
\text { assessed } \\
\end{array}$ & $\begin{array}{l}\text { Development } \\
\text { Measures }\end{array}$ & $\begin{array}{l}\text { Adjusted } \\
\text { for birth } \\
\text { weight? } \\
\end{array}$ & $\begin{array}{l}\text { Adjusted } \\
\text { for parental } \\
\text { height? }\end{array}$ & $\begin{array}{l}\text { Adjusted for } \\
\text { parental } \\
\text { education/IQ? }\end{array}$ & $\begin{array}{l}\text { Household } \\
\text { stimulation? }\end{array}$ \\
\hline $\begin{array}{l}\text { (Casale et al., } \\
\text { 2014) }\end{array}$ & $\begin{array}{l}\text { South } \\
\text { Africa }\end{array}$ & $\begin{array}{l}\text { No significant association was found } \\
\text { between stunting and social maturity. }\end{array}$ & 2 years & 4 years & $\begin{array}{l}\text { Vineland Social } \\
\text { Maturity Scale }\end{array}$ & $\begin{array}{l}\text { Yes (birth } \\
\text { weight) }\end{array}$ & $\begin{array}{l}\text { Yes } \\
\text { (maternal } \\
\text { height) }\end{array}$ & $\begin{array}{l}\text { Yes (maternal } \\
\text { education) }\end{array}$ & Yes \\
\hline $\begin{array}{l}\text { (Aubuchon- } \\
\text { Endsley et al., } \\
\text { 2011) }\end{array}$ & Ethiopia & $\begin{array}{l}\text { At } 6 \text { months, LAZ was inversely correlated } \\
\text { with both total duration of inattention }(r=- \\
0.21, p<0.05) \text { and mean inattention }(r=-0.25 \text {, } \\
p<0.05) \text {. At } 9 \text { months, there was no } \\
\text { significant association between LAZ and } \\
\text { inattention. }\end{array}$ & $\begin{array}{l}6 \\
\text { months }\end{array}$ & 9 months & $\begin{array}{l}\text { Laboratory } \\
\text { Temperament } \\
\text { Assessment } \\
\text { Battery }\end{array}$ & No & No & $\begin{array}{l}\text { Yes (maternal } \\
\text { education) }\end{array}$ & No \\
\hline $\begin{array}{l}\text { (Cheung et al., } \\
\text { 2008) }\end{array}$ & Malawi & $\begin{array}{l}\text { 1-SD increase in HAZ was associated with } \\
0.20-\mathrm{SD}(\mathrm{p}<0.01) \text { increase in social } \\
\text { development } \mathrm{z} \text {-score. }\end{array}$ & $\begin{array}{l}36 \\
\text { months }\end{array}$ & 3-6 years & $\begin{array}{l}\text { Test of } \\
\text { developmental } \\
\text { milestones }\end{array}$ & No & No & No & No \\
\hline $\begin{array}{l}\text { (Whaley et al., } \\
\text { 1998) }\end{array}$ & Kenya & $\begin{array}{l}\text { Correlation between HAZ between } 0-6 \\
\text { months and sociability behavior was } 0.26 \text { (p- } \\
\text { value }<0.01) \text {. }\end{array}$ & $\begin{array}{l}0-6 \\
\text { months }\end{array}$ & $\begin{array}{l}\text { 6-30 } \\
\text { months }\end{array}$ & BSID (MDI) & No & No & No & Yes \\
\hline $\begin{array}{l}\text { (Yang et al., } \\
\text { 2011) }\end{array}$ & Belarus & $\begin{array}{l}\text { Associations between length gain and } \\
\text { psychosocial behavior were not significant } \\
\text { after adjusting for potential confounders. }\end{array}$ & $\begin{array}{l}0-5 \\
\text { years }\end{array}$ & $\begin{array}{l}0-6.5 \\
\text { years }\end{array}$ & $\begin{array}{l}\text { Strengths and } \\
\text { Difficulties } \\
\text { Questionnaire }\end{array}$ & $\begin{array}{l}\text { Yes (birth } \\
\text { weight) }\end{array}$ & $\begin{array}{l}\text { Yes } \\
\text { (maternal } \\
\text { and paternal } \\
\text { height and } \\
\text { BMI) }\end{array}$ & $\begin{array}{l}\text { Yes (parental } \\
\text { education) }\end{array}$ & No \\
\hline $\begin{array}{l}\text { (Walker et al., } \\
\text { 2007) }\end{array}$ & Jamaica & $\begin{array}{l}\text { Stunted children reported significantly more } \\
\text { anxiety (regression coefficient: } 3.03 ; 95 \% \\
\text { CI: } 0.99,5.08) \text { and depressive symptoms } \\
(0.37 ; 95 \% \text { CI: } 0.01,0.72) \text { and lower self- } \\
\text { esteem }(21.67 ; 95 \% \text { CI: } 20.38,22.97) \text { than } \\
\text { non-stunted children and were reported by } \\
\text { their parents to be more hyperactive }(1.29 \text {; } \\
95 \% \text { CI: } 0.12,2.46) \text {. }\end{array}$ & $\begin{array}{l}9-24 \\
\text { months }\end{array}$ & $\begin{array}{l}17-18 \\
\text { years }\end{array}$ & $\begin{array}{l}\text { How I Think } \\
\text { About Myself } \\
\text { Questionnaire, } \\
\text { Manifest } \\
\text { Anxiety } \\
\text { Questionnaire, } \\
\text { Short Mood and } \\
\text { Feelings } \\
\text { Questionnaire, } \\
\text { Behavior and } \\
\text { Activities } \\
\text { Checklist, } \\
\text { Conners' Parent } \\
\text { Rating Scale }\end{array}$ & $\begin{array}{l}\text { Yes (birth } \\
\text { weight) }\end{array}$ & No & $\begin{array}{l}\text { Yes (Maternal } \\
\text { verbal } \\
\text { intelligence by } \\
\text { PPVT) }\end{array}$ & Yes \\
\hline
\end{tabular}




\begin{tabular}{|c|c|c|c|c|c|c|c|c|c|}
\hline $\begin{array}{l}\text { (S M Chang et } \\
\text { al., 2002) }\end{array}$ & Jamaica & $\begin{array}{l}\text { Stunted children had more conduct } \\
\text { difficulties (beta }=-0.087, \mathrm{p}<0.05 \text { ) than non- } \\
\text { stunted children, but there were no other } \\
\text { significant differences in behavior (i.e. } \\
\text { emotional difficulties, } \\
\text { hyperactivity/inattention, or prosocial } \\
\text { behavior reported by either parent or teacher) } \\
\text { between them. }\end{array}$ & $\begin{array}{l}9-24 \\
\text { months }\end{array}$ & $\begin{array}{l}11-12 \\
\text { years }\end{array}$ & $\begin{array}{l}\text { Rutter Teacher } \\
\text { and Parent } \\
\text { Scales }\end{array}$ & No & No & $\begin{array}{l}\text { Yes (maternal } \\
\text { education and } \\
\text { IQ using } \\
\text { PPVT) }\end{array}$ & Yes \\
\hline $\begin{array}{l}\text { (Meeks Gardner } \\
\text { et al., 1999) }\end{array}$ & Jamaica & $\begin{array}{l}\text { Stunted children were less enthusiastic when } \\
\text { exploring their environment }(\mathrm{p}<0.05) \text { and } \\
\text { showed happiness less frequently }(\mathrm{p}<0.05) \\
\text { than non-stunted children. The Child } \\
\text { behavior factor score was significantly lower } \\
\text { in the stunted children }(\mathrm{p}<0.01) \text {, which was } \\
\text { also significantly associated with a mental } \\
\text { age measure. }\end{array}$ & $\begin{array}{l}12-24 \\
\text { months }\end{array}$ & $\begin{array}{l}18-30 \\
\text { months }\end{array}$ & $\begin{array}{l}\text { Griffiths' Mental } \\
\text { Development } \\
\text { Scales }\end{array}$ & $\begin{array}{l}\text { Yes (birth } \\
\text { weight) }\end{array}$ & No & $\begin{array}{l}\text { Yes (maternal } \\
\text { verbal } \\
\text { intelligence by } \\
\text { PPVT) }\end{array}$ & Yes \\
\hline
\end{tabular}

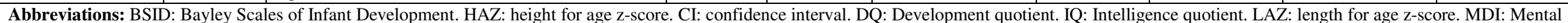
development index. PDI: psychomotor development index. PPVT: Peabody Picture Vocabulary Test. SD: Standard deviation. SE: Standard error. BMI: body mass index. 
Web Table 5C. Longitudinal Studies on Stunting and Cognitive Child Development or Learning/Schooling Milestones

\begin{tabular}{|c|c|c|c|c|c|c|c|c|}
\hline Citation & Country & Findings & $\begin{array}{l}\text { Age } \\
\text { stunting } \\
\text { assessed }\end{array}$ & $\begin{array}{l}\text { Age } \\
\text { outcome } \\
\text { assessed }\end{array}$ & $\begin{array}{l}\text { Development } \\
\text { Measures }\end{array}$ & $\begin{array}{l}\text { Adjusted } \\
\text { for birth } \\
\text { weight? }\end{array}$ & $\begin{array}{l}\text { Adjusted for } \\
\text { parental } \\
\text { height? }\end{array}$ & $\begin{array}{l}\text { Adjusted for } \\
\text { parental } \\
\text { education/IQ? }\end{array}$ \\
\hline $\begin{array}{l}\text { (S M Chang et } \\
\text { al., 2002) }\end{array}$ & Jamaica & $\begin{array}{l}\text { Stunted children had significantly lower scores in } \\
\text { arithmetic (Beta: } 4.79, \mathrm{p}<0.001 \text { ), spelling (Beta: } \\
0.10, \mathrm{p}<0.01 \text { ), word reading (Beta: } 0.84, \mathrm{p}<0.001 \text { ), } \\
\text { and reading comprehension (Beta: } 4.57, \mathrm{p}<0.01 \text { ) } \\
\text { compared to the non-stunted children. }\end{array}$ & $\begin{array}{l}9 \text { to } 24 \\
\text { months }\end{array}$ & $\begin{array}{l}11-12 \\
\text { years }\end{array}$ & $\begin{array}{l}\text { WRAT, Suffolk } \\
\text { Reading Scales }\end{array}$ & No & No & $\begin{array}{l}\text { Yes (maternal } \\
\text { education and } \\
\text { IQ using } \\
\text { PPVT) }\end{array}$ \\
\hline $\begin{array}{l}\text { (Susan M Chang } \\
\text { et al., 2010) }\end{array}$ & Jamaica & $\begin{array}{l}\text { Stunted children had worse motor skills }(\mathrm{RSCM}) \text {, } \\
\text { which were significantly related to arithmetic } \\
(\mathrm{Beta}=-1.50 ; \mathrm{p}=0.039) \text {, spelling (Beta: }-0.06 \\
\mathrm{p}=0.006) \text {, word reading (Beta }=-0.36, \mathrm{p}=0.009) \\
\text { reading comprehension }(-2.70 ; \mathrm{p}=0.014) \text {, and IQ } \\
\text { (Beta=-2.49; } \mathrm{p}=0.036)\end{array}$ & $\begin{array}{l}9-24 \\
\text { months }\end{array}$ & $\begin{array}{l}11-12 \\
\text { years }\end{array}$ & WISC-R & No & No & $\begin{array}{l}\text { Yes (maternal } \\
\text { education and } \\
\text { IQ using } \\
\text { PPVT) }\end{array}$ \\
\hline $\begin{array}{l}\text { (Walker et al., } \\
\text { 2000) }\end{array}$ & Jamaica & $\begin{array}{l}\text { Stunting was associated with lower scores on } \\
\text { several cognitive tests: (1) WISC-R/Full-Scale: } \\
7.48 \text { (SE: } 2.08, \text { p<0.001); (2) WISC- } \\
\text { R/Performance: } 7.17 \text { (SE: } 2.44, \text { p<0.01); (3) WISC- } \\
\text { R/Verbal: } 6.93 \text { (SE: 1.87, p<0.001); (4) RPM: } 3.05 \\
\text { (SE: 0.91, p<0.001); (5) PPVT: 7.88 (SE: } 2.78, \\
\text { p<0.01); (6) Analogies: } 1.25 \text { (SE: } 0.53, \text { p<0.05); } \\
\text { and (7) Vocabulary: } 3.94 \text { (SE: } 1.26, p<0.01) .\end{array}$ & $\begin{array}{l}9-24 \\
\text { months }\end{array}$ & $\begin{array}{l}11-12 \\
\text { years }\end{array}$ & $\begin{array}{l}\text { WISC-R, RPM, PPVT, } \\
\text { Stanford Binet, auditory } \\
\text { working memory, digit } \\
\text { span forwards, digit } \\
\text { span backwards, visual- } \\
\text { spatial memory, Corsi } \\
\text { blocks, visual } \\
\text { information processing, } \\
\text { sustained attention, } \\
\text { Stroop Test }\end{array}$ & No & No & $\begin{array}{l}\text { Yes (maternal } \\
\text { education and } \\
\text { IQ using } \\
\text { PPVT) }\end{array}$ \\
\hline $\begin{array}{l}\text { (Berkman et al., } \\
\text { 2002) }\end{array}$ & Peru & $\begin{array}{l}\text { Children severely stunted at age two scored } 10 \\
\text { points lower on the WISC-R test ( } 95 \% \text { CI: }-2.4 \text {, } \\
17.5, p=0.011) \text { compared to non- or not severely- } \\
\text { stunted children. }\end{array}$ & $\begin{array}{l}\text { Birth to } \\
2 \text { years }\end{array}$ & 9 years & WISC-R & No & No & $\begin{array}{l}\text { Yes (maternal } \\
\text { and paternal } \\
\text { education) }\end{array}$ \\
\hline $\begin{array}{l}\text { (Cheung \& } \\
\text { Ashorn, 2010) }\end{array}$ & Philippines & $\begin{array}{l}\text { 1-SD increase in HAZ was associated with a } 0.24 \\
\text { unit }(\mathrm{CI}: 0.17-0.31, \mathrm{p}<0.001) \text { increase in cognition. }\end{array}$ & $\begin{array}{l}6-24 \\
\text { months }\end{array}$ & 11 years & PNIT & No & No & $\begin{array}{l}\text { Yes (maternal } \\
\text { education) }\end{array}$ \\
\hline $\begin{array}{l}\text { (Hamadani et al., } \\
\text { 2012) }\end{array}$ & Bangladesh & $\begin{array}{l}\text { 1-SD increase in HAZ was associated with } 0.27 \mathrm{SD} \\
\text { (SE: 0.082) increase in WPPSI IQ and } 0.17(\mathrm{p} \\
<0.001) \text { increase in Bayley score. }\end{array}$ & $\begin{array}{l}15 \\
\text { months }\end{array}$ & $\begin{array}{l}18,24 \\
\text { months }\end{array}$ & $\begin{array}{l}\text { BSID-II; WPPSI, } \\
\text { Movement Assessment } \\
\text { Battery for Children }\end{array}$ & $\begin{array}{l}\text { Yes } \\
\text { (gestation } \\
\text { al age) }\end{array}$ & No & $\begin{array}{l}\text { Yes (parental } \\
\text { education) }\end{array}$ \\
\hline $\begin{array}{l}\text { (Hamadani et al., } \\
\text { 2014) }\end{array}$ & Bangladesh & $\begin{array}{l}\text { 1-SD increase in LAZ score between birth and } 12 \\
\text { months and } 12-24 \text { months was associated with } \\
0.13-S D(C I: 0.09-0.17, \mathrm{p}<0.001) \text { and } 0.11-S D \\
\text { (CI: 0.07- } 0.14, \text { p }<0.001) \text { increase in } \mathrm{z} \text { scores for } \\
\text { WPPSI, respectively. From } 24-64 \text { months, a 1-SD }\end{array}$ & $\begin{array}{l}\text { Birth to } \\
64 \\
\text { months }\end{array}$ & $\begin{array}{l}7,18,64 \\
\text { months }\end{array}$ & BSID-II; WPPSI & $\begin{array}{l}\text { Yes (birth } \\
\text { length) }\end{array}$ & $\begin{array}{l}\text { Yes (maternal } \\
\text { BMI) }\end{array}$ & $\begin{array}{l}\text { Yes (maternal } \\
\text { and paternal } \\
\text { education) }\end{array}$ \\
\hline
\end{tabular}




\begin{tabular}{|c|c|c|c|c|c|c|c|c|}
\hline & & $\begin{array}{l}\text { increase in LAZ was associated with } 0.06-\mathrm{SD}(\mathrm{CI} \text { : } \\
0.02-0.1, \mathrm{p}=0.002) \text { increase in WPPSI score. }\end{array}$ & & & & & & \\
\hline $\begin{array}{l}\text { (Niehaus et al., } \\
\text { 2002) }\end{array}$ & Brazil & $\begin{array}{l}\text { There was no significant association between HAZ } \\
\text { and TONI-III score }\left(\mathrm{R}^{2}=0.27, \mathrm{p}=0.13\right)\end{array}$ & 2 years & $\begin{array}{l}6-10 \\
\text { years }\end{array}$ & $\begin{array}{l}\text { TONI-III, WISC-III, } \\
\text { WRAT }\end{array}$ & $\begin{array}{l}\text { Yes (birth } \\
\text { weight) }\end{array}$ & No & $\begin{array}{l}\text { Yes (maternal } \\
\text { education) }\end{array}$ \\
\hline $\begin{array}{l}\text { (Pollitt et al., } \\
\text { 1993) }\end{array}$ & Guatemala & $\begin{array}{l}\text { 1-SD increase in LAZ is associated with a } \\
\text { standardized mean difference of } 0.17-\mathrm{SD} \text { (SE: } \\
0.06 \text { ) in cognition. }\end{array}$ & 2 years & 4 years & $\begin{array}{l}\text { Brazelton Neonatal } \\
\text { Assessment, Composite } \\
\text { Infant Scale and } \\
\text { Preschool Battery }\end{array}$ & No & No & $\begin{array}{l}\text { Yes (maternal } \\
\text { education) }\end{array}$ \\
\hline $\begin{array}{l}\text { (Adair et al., } \\
\text { 2013) }\end{array}$ & $\begin{array}{l}\text { Brazil, } \\
\text { Guatemala, } \\
\text { India, } \\
\text { Philippines, } \\
\text { South } \\
\text { Africa }\end{array}$ & $\begin{array}{l}\text { 1-SD increase in conditional height at } 2 \text { years was } \\
\text { associated with } 0.47 \text { ( } 95 \% \text { CI: } 0.39-0.56) \text { more } \\
\text { years of schooling. Faster linear growth at age } 2 \\
\text { years was strongly associated with the risk of not } \\
\text { completing secondary school }(0.74 ; 95 \% \text { CI: } 0.67 \text { - } \\
0.78) \text {. }\end{array}$ & 2 years & $\begin{array}{l}18-31 \\
\text { years }\end{array}$ & $\begin{array}{l}\text { Years of schooling; } \\
\text { Completing secondary } \\
\text { school }\end{array}$ & $\begin{array}{l}\text { Yes } \\
\text { (gestation } \\
\text { al age) }\end{array}$ & $\begin{array}{l}\text { Yes (maternal } \\
\text { height) }\end{array}$ & $\begin{array}{l}\text { Yes (maternal } \\
\text { education) }\end{array}$ \\
\hline $\begin{array}{l}\text { (Alberto } \\
\text { Camargo- } \\
\text { Figuera et al., } \\
\text { 2014) }\end{array}$ & Brazil & $\begin{array}{l}\text { Stunting at age one year was associated with } \\
\text { double the odds of low IQ (less than } 1 \text { SD from the } \\
\text { median standardized IQ) ( } 95 \% \text { CI: } 1.6-2.5 \text {, } \\
\text { p }<0.0001 \text { ). In the fully adjusted logistic model, HA } \\
\text { deficit was associated with } 1.3 \text { (95\% CI: } 1.0-1.7 \text {, } \\
\text { p=0.05) higher odds of low IQ }\end{array}$ & $\begin{array}{l}3 \text { months, } \\
1 \text { year, } \\
6 \text { years }\end{array}$ & 6 years & WISC-III & $\begin{array}{l}\text { Yes (low } \\
\text { birth } \\
\text { weight) }\end{array}$ & No & $\begin{array}{l}\text { Yes (maternal } \\
\text { education) }\end{array}$ \\
\hline $\begin{array}{l}\text { (Aurino \& } \\
\text { Burchi, 2014) }\end{array}$ & $\begin{array}{l}\text { Ethiopia, } \\
\text { India, Peru, } \\
\text { Vietnam }\end{array}$ & $\begin{array}{l}1 \text { SD increase in HAZ was associated with an } \\
\text { increment of between } 3 \text { and } 8 \text { per cent of an SD in } \\
\text { PPVT, and with an increase of between } 5 \text { and } 10 \\
\text { percent and between } 4 \text { and } 8 \text { percent of a SD in } \\
\text { CDA and Math scores, respectively. }\end{array}$ & $\begin{array}{l}6-18 \\
\text { months, } \\
4-5 \text { years }\end{array}$ & $\begin{array}{l}4-5 \\
\text { years, } \\
7-8 \text { years }\end{array}$ & $\begin{array}{l}\text { PPVT, Cognitive } \\
\text { Development } \\
\text { Assessment, } \\
\text { Mathematics test }\end{array}$ & No & No & $\begin{array}{l}\text { Yes (household } \\
\text { head } \\
\text { education) }\end{array}$ \\
\hline $\begin{array}{l}\text { (Casale et al., } \\
\text { 2014) }\end{array}$ & $\begin{array}{l}\text { South } \\
\text { Africa }\end{array}$ & $\begin{array}{l}\text { Being stunted was associated with } 2.41 \text { (SE: } 0.37 \text {, } \\
\mathrm{p}<0.01 \text { ) lower score on the R-DPDQ in unadjusted } \\
\text { models and } 0.18 \text { lower score (SE: } 0.36, p<0.01 \text { ) in } \\
\text { fully adjusted models. }\end{array}$ & 2 years & 5 years & $\begin{array}{l}\text { Revised-Denver } \\
\text { Prescreening } \\
\text { Developmental } \\
\text { Questionnaire (R- } \\
\text { DPDQ) }\end{array}$ & $\begin{array}{l}\text { Yes (birth } \\
\text { weight) }\end{array}$ & $\begin{array}{l}\text { Yes (maternal } \\
\text { height) }\end{array}$ & $\begin{array}{l}\text { Yes (maternal } \\
\text { education) }\end{array}$ \\
\hline $\begin{array}{l}\text { (Crookston et } \\
\text { al., 2013) }\end{array}$ & $\begin{array}{l}\text { Ethiopia, } \\
\text { India, Peru, } \\
\text { Vietnam }\end{array}$ & $\begin{array}{l}\text { Across all four countries, compared with never } \\
\text { stunted children, } \\
\text { - persistently stunted children had higher odds of } \\
\text { being overage for grade (ORs ranging from } 1.71 \text { - } \\
2.79 \text { ); those who became stunted at age } 8 \text { had } \\
\text { ORs of } 1.35-2.40 \text {; and those who recovered from } \\
\text { stunting by age } 8 \text { had ORs of } 0.85-2.20 \\
\text { persistently stunted children had } 0.22-0.48 \text { lower } \\
\text { mathematics scores; those who recovered from } \\
\text { stunting had } 0.12-0.21 \text { lower scores; there was no }\end{array}$ & $\begin{array}{l}1 \text { year, } \\
7-8 \text { years }\end{array}$ & $7-8$ years & $\begin{array}{l}\text { Mathematics, reading } \\
\text { comprehension, PPVT, } \\
\text { overage for grade }\end{array}$ & No & No & $\begin{array}{l}\text { Yes (maternal } \\
\text { and paternal } \\
\text { education) }\end{array}$ \\
\hline
\end{tabular}




\begin{tabular}{|c|c|c|c|c|c|c|c|c|}
\hline & & $\begin{array}{l}\text { difference for children who became stunted at } \\
\text { age } 8 \text {. } \\
\text { - persistently stunted children had } 0.13-0.31 \\
\text { lower PPVT scores; those who became stunted } \\
\text { had } 0.07-0.24 \text { lower scores; and those who } \\
\text { recovered from stunting had } 0.01-0.25 \text { lower } \\
\text { scores in PPVT. } \\
\text { - persistently stunted children had } 0.24-0.38 \text { lower } \\
\text { reading comprehension scores; those who } \\
\text { became stunted had } 0.05-0.37 \text { lower scores; and } \\
\text { those who recovered from stunting had } 0.10-0.23 \\
\text { lower scores. }\end{array}$ & & & & & & \\
\hline $\begin{array}{l}\text { (Mendez \& } \\
\text { Adair, 1999) }\end{array}$ & Philippines & $\begin{array}{l}\text { At age } 8 \text { years, children with severe early stunting } \\
\text { had mean cognitive scores } 0.61 \mathrm{SD} \text { below the mean } \\
\text { for non-stunted children }(\mathrm{P}<0.000) \text {. This was more } \\
\text { than twice the shortfall in children with moderate } \\
\text { stunting, whose mean scores were } 0.25 \mathrm{SD} \text { lower } \\
\text { than those of non-stunted children }(\mathrm{P}<0.001) \text {. }\end{array}$ & $\begin{array}{c}0-2 \\
\text { years }\end{array}$ & $\begin{array}{l}8-11 \\
\text { years }\end{array}$ & $\begin{array}{l}\text { PNIT, English (reading } \\
\text { comprehension) and } \\
\text { Mathematics } \\
\text { achievement tests (at } \\
\text { age 11) }\end{array}$ & $\begin{array}{l}\text { Yes (birth } \\
\text { weight) }\end{array}$ & $\begin{array}{l}\text { maternal } \\
\text { height }\end{array}$ & $\begin{array}{l}\text { Yes (maternal } \\
\text { and paternal } \\
\text { education) }\end{array}$ \\
\hline (Sanchez, 2013) & $\begin{array}{l}\text { Ethiopia, } \\
\text { India, Peru, } \\
\text { Vietnam }\end{array}$ & $\begin{array}{l}\text { 1-SD improvement in HAZ at } 4 \text { to } 5 \text { years tends to } \\
\text { increase cognitive ability at } 7 \text { to } 8 \text { years by } 9 \% \text {, } \\
15 \%, 11 \% \text { and } 11 \% \text {, and increase cognitive ability } \\
\text { during adolescence (14-15 years) by } 6 \%, 9 \%, 17 \% \\
\text { and } 7 \% \text { in Peru, India, Vietnam and Ethiopia, } \\
\text { respectively. }\end{array}$ & $\begin{array}{l}1-2,4-5, \\
\text { and } 7-8 \\
\text { years }\end{array}$ & $\begin{array}{l}7-8,11- \\
12,14- \\
15 \text { years }\end{array}$ & $\begin{array}{l}\text { PPVT, numeracy, math, } \\
\text { reading comprehension }\end{array}$ & No & No & $\begin{array}{l}\text { Yes (maternal } \\
\text { education) }\end{array}$ \\
\hline
\end{tabular}

Abbreviations: BSID: Bayley Scales of Infant Development ( $2^{\text {nd }}$ version). CAT: Cognitive Abilities Test. HAZ: height for age z-score. CI: confidence interval. DQ: Development quotient. IQ: Intelligence

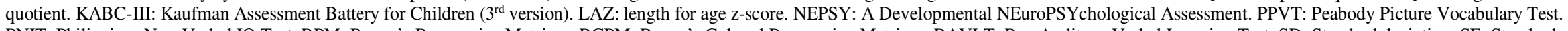

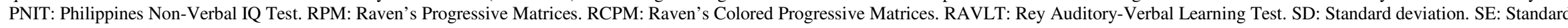

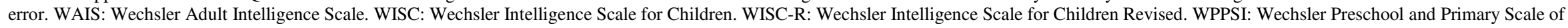
Intelligence. WRAT: Wide Range Achievement Test. RSCM: rapid sequential continuous movements 
Web Table 6. Quasi-experimental Studies on Stunting and Cognitive Child Development or Learning/Schooling Milestones

\begin{tabular}{|c|c|c|c|c|c|c|c|c|c|}
\hline Citation & Country & Findings & $\begin{array}{l}\text { Age } \\
\text { stunting } \\
\text { assessed }\end{array}$ & $\begin{array}{l}\text { Age } \\
\text { outcome } \\
\text { assessed }\end{array}$ & $\begin{array}{l}\text { Development } \\
\text { Measures }\end{array}$ & $\begin{array}{l}\text { Adjusted } \\
\text { for birth } \\
\text { weight? }\end{array}$ & $\begin{array}{l}\text { Adjusted } \\
\text { for parental } \\
\text { height? }\end{array}$ & $\begin{array}{l}\text { Adjusted for } \\
\text { parental } \\
\text { education/IQ? }\end{array}$ & $\begin{array}{l}\text { Method } \\
\text { used }\end{array}$ \\
\hline $\begin{array}{l}\text { (Dercon \& } \\
\text { Porter, 2014) }\end{array}$ & Ethiopia & $\begin{array}{l}\text { Children who were in utero during a } \\
\text { famine or exposed to a famine within } \\
\text { the first } 36 \text { months were } 3.9 \mathrm{~cm} \\
\text { shorter. Exposure between } 2-3 \text { years of } \\
\text { life was associated with a } 2 \% \text { lower } \\
\text { likelihood of finishing primary school. }\end{array}$ & $\begin{array}{l}\text { 12-36 } \\
\text { months }\end{array}$ & $\begin{array}{l}19-22 \\
\text { years }\end{array}$ & $\begin{array}{l}\text { Completion of } \\
\text { primary school }\end{array}$ & No & No & No & $\begin{array}{l}\text { DD, IV, } \\
\text { household } \\
\text { fixed } \\
\text { effects }\end{array}$ \\
\hline $\begin{array}{l}\text { (Umana-Aponte, } \\
\text { 2011) }\end{array}$ & Uganda & $\begin{array}{l}\text { Cohort exposed to famine in utero } \\
\text { earned } 0.364 \text { fewer years of schooling, } \\
\text { was } 4.2 \% \text { less likely to complete } \\
\text { primary school, and was } 3.1 \% \text { less } \\
\text { likely to be literate. With family fixed } \\
\text { effects, children exposed to famine in } \\
\text { utero were } 7-10 \% \text { less likely to ever } \\
\text { attend school. }\end{array}$ & $\begin{array}{l}\text { In utero } \\
\text { to } 5 \\
\text { years }\end{array}$ & $\begin{array}{l}10-14 \\
\text { years }\end{array}$ & $\begin{array}{l}\text { Ever attending } \\
\text { school, currently } \\
\text { attending school, } \\
\text { primary school } \\
\text { completion, literacy }\end{array}$ & No & No & No & $\begin{array}{l}\text { IV, family- } \\
\text { fixed } \\
\text { effects, } \\
\text { sibling } \\
\text { design }\end{array}$ \\
\hline $\begin{array}{l}\text { (Leight et al., } \\
\text { 2015) }\end{array}$ & China & $\begin{array}{l}\text { 1-SD increase in rainfall in two periods } \\
\text { in utero and in the first year led to } 0.1- \\
0.2 \text { SD lower achievement in test } \\
\text { scores at } 9-12 \text { years. There was little } \\
\text { evidence of a significant impact of } \\
\text { rainfall in the second year of life, when } \\
\text { the coefficients varied in sign. There } \\
\text { was also evidence that, over time, } \\
\text { children exposed to adverse shocks } \\
\text { catch up with their peers who did not } \\
\text { experience any shocks. By the second } \\
\text { wave of the survey, at which point the } \\
\text { children were between } 13 \text { and } 16 \text { years } \\
\text { old, the effect of shocks on cognitive } \\
\text { skills was attenuated. }\end{array}$ & $\begin{array}{l}\text { In utero } \\
\text { to } 16 \\
\text { years }\end{array}$ & $\begin{array}{l}9-12 \\
\text { years, } \\
12-16 \\
\text { years, } \\
17-21 \\
\text { years }\end{array}$ & $\begin{array}{l}\text { General cognitive } \\
\text { ability test, grade- } \\
\text { specific Chinese and } \\
\text { mathematics } \\
\text { achievement tests, } \\
\text { literacy or "life } \\
\text { skills" tests }\end{array}$ & No & No & No & IV \\
\hline $\begin{array}{l}\text { (Outes-Leon et } \\
\text { al., 2011) }\end{array}$ & Peru & $\begin{array}{l}\text { 1-SD increase in HAZ was associated } \\
\text { with a } 17.2 \text { (SE: } 7.9 \text { ) to } 20.7 \text { (SE: } 5.9 \text { ) } \\
\text { percent SD increase in PPVT score, } \\
\text { depending on model specification. }\end{array}$ & $\begin{array}{l}6-18 \\
\text { months, } \\
4-5 \\
\text { years, } 7- \\
8 \text { years }\end{array}$ & $\begin{array}{l}6-18 \\
\text { months, } \\
4-5 \\
\text { years, } 7- \\
8 \text { years }\end{array}$ & PPVT & No & No & No & $\begin{array}{l}\text { IV, } \\
\text { Household } \\
\text { fixed } \\
\text { effects, } \\
\text { sibling } \\
\text { design }\end{array}$ \\
\hline
\end{tabular}




\begin{tabular}{|c|c|c|c|c|c|c|c|c|c|}
\hline $\begin{array}{l}\text { (Glewwe et al., } \\
\text { 2001) }\end{array}$ & Philippines & $\begin{array}{l}\text { 1-SD increase in height was associated } \\
\text { with improvement in the achievement } \\
\text { test score by } 5.0 \text { (SE: } 2.2 \text { ) points. }\end{array}$ & $4-5$ years & $\begin{array}{l}8-11 \\
\text { years }\end{array}$ & $\begin{array}{l}\text { Academic production } \\
\text { function which is a } \\
\text { sum of age of } \\
\text { enrollment, time } \\
\text { spent in school, and } \\
\text { time not in school. }\end{array}$ & No & No & $\begin{array}{l}\text { Yes (maternal } \\
\text { education) }\end{array}$ & $\begin{array}{l}\text { IV, } \\
\text { Household } \\
\text { fixed } \\
\text { effects, } \\
\text { sibling } \\
\text { design }\end{array}$ \\
\hline $\begin{array}{l}\text { (Glewwe \& } \\
\text { King, 2001) }\end{array}$ & Philippines & $\begin{array}{l}\text { From OLS models controlling for } \\
\text { growth in various periods, one cm } \\
\text { increase in height between age } 0-12 \\
\text { months would increase IQ by } 0.50 \\
\text { points (SE: } 0.10 \text { ) while growth from } \\
12-24 \text { months would increase IQ by } \\
0.93 \text { points (SE: } 0.12 \text { ). After using } \\
\text { IVs, only growth during } 12-24 \text { months } \\
\text { was significantly associated with IQ. }\end{array}$ & $\begin{array}{l}0-12 \\
\text { months, } \\
12-24 \\
\text { months, } \\
2-8 \text { years }\end{array}$ & 8 years & $\begin{array}{l}\text { Philippines Non- } \\
\text { Verbal Intelligence } \\
\text { Test }\end{array}$ & $\begin{array}{l}\text { Yes (birth } \\
\text { weight) }\end{array}$ & $\begin{array}{l}\text { Yes } \\
\text { (maternal } \\
\text { height) }\end{array}$ & $\begin{array}{l}\text { Yes (maternal } \\
\text { and paternal } \\
\text { education) }\end{array}$ & IV \\
\hline
\end{tabular}

Abbreviations: BSID: Bayley Scales of Infant Development ( $2^{\text {nd }}$ version). CAT: Cognitive Abilities Test. HAZ: height for age z-score. CI: confidence interval. DQ: Development quotient. IQ: Intelligence

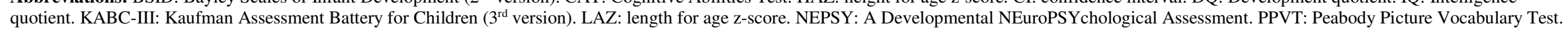

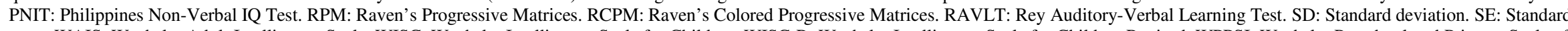

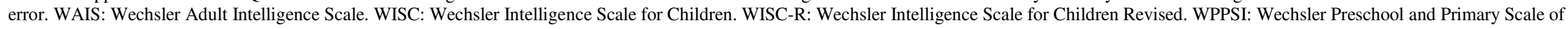
Intelligence. WRAT: Wide Range Achievement Test.; OLS: Ordinary Least Square regression; DD: Difference in Difference; IV: Instrumental Variable 
Web Table 7. Randomized Experimental Cash Transfer Programs and Cognitive Child Development or Learning/Schooling Milestones

\begin{tabular}{|c|c|c|c|c|c|c|c|c|}
\hline Citation & Country & Findings & $\begin{array}{l}\text { Age } \\
\text { stunting } \\
\text { assessed }\end{array}$ & $\begin{array}{l}\text { Age } \\
\text { outcome } \\
\text { assessed }\end{array}$ & Development Measures & $\begin{array}{l}\text { Adjusted } \\
\text { for birth } \\
\text { weight? }\end{array}$ & $\begin{array}{l}\text { Adjusted } \\
\text { for parental } \\
\text { height? }\end{array}$ & $\begin{array}{l}\text { Adjusted for } \\
\text { parental } \\
\text { education/IQ? }\end{array}$ \\
\hline $\begin{array}{l}\text { (Fernald et al., } \\
\text { 2008) }\end{array}$ & Mexico & $\begin{array}{l}\text { Receiving cash transfers led to a } 0.20-\mathrm{SD}(95 \% \\
\text { CI: } 0.09-0.30) \text { increase in HAZ, and } 0.12(95 \% \\
\text { CI: 0.04-0.19), 0.13 (95\% CI: 0.07-0.19), } 0.08 \\
\text { (95\% CI: } 0.01-0.14) \text {, and 0.18 (95\% CI: 0.08- } \\
\text { 0.27) SD increases in long-term memory, short- } \\
\text { term memory, visual integration, and receptive } \\
\text { vocabulary respectively. }\end{array}$ & $\begin{array}{l}0-68 \\
\text { months }\end{array}$ & $\begin{array}{l}\text { 24-68 } \\
\text { months }\end{array}$ & $\begin{array}{l}\text { Woodcock-Munoz (Spanish } \\
\text { version), PPVT (Spanish } \\
\text { version), }\end{array}$ & No & No & $\begin{array}{l}\text { Yes (maternal } \\
\text { and paternal } \\
\text { education) }\end{array}$ \\
\hline $\begin{array}{l}\text { (Fernald et al., } \\
\text { 2009) }\end{array}$ & Mexico & $\begin{array}{l}\text { Almost } 10 \text { years after the programme began, } \\
\text { children who received cash transfers had a } \\
0.03-\text { SD (95\% CI: } 0.01-0.05 \text { ) increase in HAZ } \\
\text { and } 0.73 \text { (95\% CI: } 0.48-0.99 \text { ) and } 0.47 \text { ( } 95 \% \\
\text { CI: } 0.19-0.74) \text { SD increases in verbal and } \\
\text { cognitive assessments, respectively. }\end{array}$ & $0-2$ years & $\begin{array}{l}8-10 \\
\text { years }\end{array}$ & WISC-R & No & No & $\begin{array}{l}\text { Yes (maternal } \\
\text { and paternal } \\
\text { education) }\end{array}$ \\
\hline $\begin{array}{l}\text { (Fernald \& } \\
\text { Hidrobo, 2011) }\end{array}$ & Ecuador & $\begin{array}{l}\text { Program receipt associated with } 5.24 \text { (CI: } 1.28 \text { - } \\
9.20 \text { ) increase in language skills score for rural } \\
\text { children. There were no significant differences } \\
\text { in height. }\end{array}$ & $\begin{array}{l}0-36 \\
\text { months }\end{array}$ & $\begin{array}{l}36 \\
\text { months } \\
\text { or } \\
\text { younger }\end{array}$ & $\begin{array}{l}\text { Fundación MacArthur } \\
\text { Inventorio del Desarrollo } \\
\text { de Habilidades } \\
\text { Comunicativas - Breve } \\
\text { (IDHC-B), MacArthur- } \\
\text { Bates Communicative } \\
\text { Development Inventory } \\
\text { (CDI) (Spanish/Short } \\
\text { versions) }\end{array}$ & No & No & $\begin{array}{l}\text { Yes (maternal } \\
\text { education) }\end{array}$ \\
\hline $\begin{array}{l}\text { (Macours et al., } \\
\text { 2012) }\end{array}$ & Nicaragua & $\begin{array}{l}\text { Cash transfer program receipt (joint treatment) } \\
\text { was associated with: } 0.13 \text { (SE: } 0.06 \text { ) and } 0.17 \\
\text { (SE: 0.06) SD increases in the social and } \\
\text { language components of the Denver test and a } \\
0.22 \text { SD (SE: } 0.08 \text { ) increase in PPVT score. } \\
\text { There were no significant differences in height. }\end{array}$ & $0-6$ years & 3-9 years & $\begin{array}{l}\text { Denver Developmental } \\
\text { Screening Test, PPVT } \\
\text { (Spanish), short-term } \\
\text { memory test }\end{array}$ & No & No & $\begin{array}{l}\text { Yes (maternal } \\
\text { and paternal } \\
\text { education) }\end{array}$ \\
\hline $\begin{array}{l}\text { (Paxson \& } \\
\text { Schady, 2010) }\end{array}$ & Ecuador & $\begin{array}{l}\text { Cash transfer program was on average } \\
\text { associated with 5\% SD increase in cognitive } \\
\text { measures (vocabulary recognition, long-term } \\
\text { memory, short-term memory, visual } \\
\text { integration), with SE of } 7 \% \text {. There were no } \\
\text { significant differences in height. }\end{array}$ & $\begin{array}{l}3-7 \text { years } \\
\text { (average } \\
\text { age }<5 \text { yrs) }\end{array}$ & 3-7 years & $\begin{array}{l}\text { PPVT (Spanish), } \\
\text { Woodcock-Johnson-Munoz }\end{array}$ & No & No & $\begin{array}{l}\text { Yes (maternal } \\
\text { education and } \\
\text { PPVT) }\end{array}$ \\
\hline
\end{tabular}

Abbreviations: BSID: Bayley Scales of Infant Development ( ${ }^{\text {nd }}$ version). CAT: Cognitive Abilities Test. HAZ: height for age z-score. CI: confidence interval. DQ: Development quotient. IQ: Intelligence

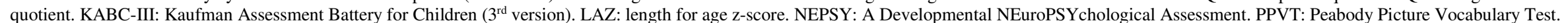

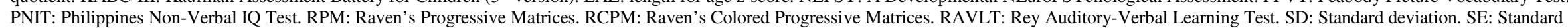




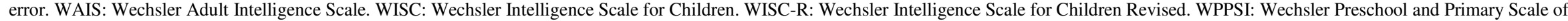
Intelligence. WRAT: Wide Range Achievement Test. 
Web Table 8A. Nutrition Supplementation Intervention Studies on Stunting and Gross Motor and Fine Motor Child Development

\begin{tabular}{|c|c|c|c|c|c|}
\hline Citation & Country & Findings & $\begin{array}{l}\text { Age of } \\
\text { enrollment }\end{array}$ & $\begin{array}{l}\text { Age of } \\
\text { assessment }\end{array}$ & Development measures \\
\hline $\begin{array}{l}\text { (Grantham- } \\
\text { McGregor et al., } \\
\text { 1991) }\end{array}$ & Jamaica & $\begin{array}{l}\text { Supplementation }(1 \mathrm{~kg} \text { milk-based formula per week) was associated with a } 6.6 \\
\text { unit }(95 \% \text { CI: } 2.3 ; 10.9) \text { increase in locomotor skills from enrollment to age } 12 \\
\text { months and } 12.4 \text { units }(5.4 ; 19.5) \text { units from enrollment to } 24 \text { months. }\end{array}$ & $\begin{array}{l}9-24 \\
\text { months }\end{array}$ & $\begin{array}{l}12 \text { months, } \\
24 \text { months }\end{array}$ & Griffith's Mental development Scale \\
\hline $\begin{array}{l}\text { (Grantham- } \\
\text { McGregor et al., } \\
\text { 1997) }\end{array}$ & Jamaica & $\begin{array}{l}\text { Four years after the end of the two-year supplementation intervention }(1 \mathrm{~kg} \\
\text { milk-based formula per week), there was only a very small global benefit of } \\
\text { supplementation detected. }\end{array}$ & $\begin{array}{l}9-24 \\
\text { months }\end{array}$ & $7-8$ years & $\begin{array}{l}\text { Digit span, Corsi blocks. Lafayette } \\
\text { Grooved Pegboard Test }\end{array}$ \\
\hline $\begin{array}{l}\text { (Susan M Chang } \\
\text { et al., 2010) }\end{array}$ & Jamaica & $\begin{array}{l}\text { No significant differences in fine motor skills were observed due to } \\
\text { supplementation (effect sizes in SDs: } 0.08 \text { for RSCM and } 0.04 \text { for dexterity). }\end{array}$ & $\begin{array}{l}9-24 \\
\text { months }\end{array}$ & $11-12$ years & $\begin{array}{l}\text { Grooved Pegboard, Bruininks- } \\
\text { Oseretsky Test of Motor Proficiency, } \\
\text { Neurological Examination of Soft } \\
\text { Signs, Finger tap }\end{array}$ \\
\hline $\begin{array}{l}\text { (Nahar et al., } \\
\text { 2012) }\end{array}$ & Bangladesh & $\begin{array}{l}\text { Food supplementation (distribution of cereal-based food packets }(150-300 \\
\text { kcal/day) for } 3 \text { months) alone did not show a significant benefit in motor } \\
\text { development or growth. }\end{array}$ & $\begin{array}{l}6-24 \\
\text { months }\end{array}$ & $\begin{array}{l}9-30 \\
\text { months }\end{array}$ & BSID-II (PDI) \\
\hline $\begin{array}{l}\text { (Waber et al., } \\
\text { 1981) }\end{array}$ & Colombia & $\begin{array}{l}\text { Food supplementation significantly improved locomotor skills }(\mathrm{F}=15.9 \text {, } \\
\mathrm{p}<0.001) \text { and hand-eye coordination }(\mathrm{F}=7.25, \mathrm{p}=0.008)\end{array}$ & $\begin{array}{l}\text { 3rd } \\
\text { trimester- } \\
\text { 3years }\end{array}$ & 3 years & Griffith's Mental development Scale \\
\hline $\begin{array}{l}\text { (Vazir et al., } \\
\text { 2012) }\end{array}$ & India & $\begin{array}{l}\text { There were no significant differences in the Motor Development Index among } \\
\text { the three intervention groups, before and after adjusting for important } \\
\text { covariates. }\end{array}$ & 3 months & $\begin{array}{l}6,9,2,15 \\
\text { months }\end{array}$ & BSID-II \\
\hline
\end{tabular}

Abbreviations: BSID: Bayley Scales of Infant Development. HAZ: height for age z-score. CI: confidence interval. DQ: Development quotient. IQ: Intelligence quotient. LAZ: length for age z-score. MDI: Mental development index. PDI: psychomotor development index. SD: Standard deviation. SE: Standard error. 
Web Table 8B. Nutrition Supplementation Intervention Studies on Stunting and Psychosocial Child Development

\begin{tabular}{|c|c|c|c|c|c|}
\hline Citation & Country & Findings & $\begin{array}{l}\text { Age of } \\
\text { enrollment }\end{array}$ & $\begin{array}{l}\text { Age of } \\
\text { assessment }\end{array}$ & Development measures \\
\hline $\begin{array}{l}\text { (Meeks } \\
\text { Gardner et al., } \\
1999)\end{array}$ & Jamaica & $\begin{array}{l}\text { Supplementation predicted mental age at } 12 \text { and } 24 \text { months after intervention } \\
\text { enrollment, but had no significant effect on behavior. }\end{array}$ & $\begin{array}{l}12-24 \\
\text { months }\end{array}$ & $\begin{array}{l}18-30 \\
\text { months }\end{array}$ & Griffiths' Mental Development Scales \\
\hline (Walker, 2006) & Jamaica & $\begin{array}{l}\text { Sixteen years after the end of the two-year supplementation intervention }(1 \mathrm{~kg} \\
\text { milk-based formula per week), there was no significant effect }(\mathrm{F}=1.505, \mathrm{P}= \\
0.17) \text { on psychosocial functioning of stunted children. }\end{array}$ & $\begin{array}{l}9-24 \\
\text { months }\end{array}$ & $17-18$ years & $\begin{array}{l}\text { How I Think About Myself } \\
\text { Questionnaire, Short Mood and } \\
\text { Feelings Questionnaire, Manifest } \\
\text { Anxiety Questionnaire, Behavior and } \\
\text { Activities Checklist, Conners' Parent } \\
\text { Rating Scale }\end{array}$ \\
\hline $\begin{array}{l}\text { (Nahar et al., } \\
\text { 2012) }\end{array}$ & Bangladesh & $\begin{array}{l}\text { Food supplementation (distribution of cereal-based food packets (150-300 } \\
\text { kcal/day) for } 3 \text { months) alone did not show a significant benefit in development } \\
\text { or growth. }\end{array}$ & $\begin{array}{l}6-24 \\
\text { months }\end{array}$ & $\begin{array}{l}9-30 \\
\text { months }\end{array}$ & BSID-II (PDI) \\
\hline $\begin{array}{l}\text { (Waber et al., } \\
\text { 1981) }\end{array}$ & Colombia & $\begin{array}{l}\text { Nutritional supplementation improved behavior in the short-term but waned } \\
\text { over time. }\end{array}$ & $\begin{array}{l}\text { 3rd } \\
\text { trimester- } \\
\text { 3years }\end{array}$ & 3 years & Griffith's Mental development Scale \\
\hline
\end{tabular}

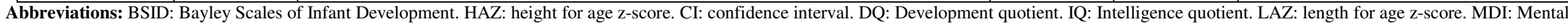
development index. PDI: psychomotor development index. PPVT: Peabody Picture Vocabulary Test. SD: Standard deviation. SE: Standard error. 
Web Table 8C. Nutrition Supplementation Intervention Studies on Stunting and Child Cognitive Development or Learning/Schooling Milestones

\begin{tabular}{|c|c|c|c|c|c|}
\hline Citation & Country & Findings & $\begin{array}{c}\text { Age of } \\
\text { enrollment }\end{array}$ & $\begin{array}{c}\text { Age of } \\
\text { assessment }\end{array}$ & Development measures \\
\hline $\begin{array}{l}\text { (Grantham- } \\
\text { McGregor et } \\
\text { al., 1991) }\end{array}$ & Jamaica & $\begin{array}{l}\text { Supplementation }(1 \mathrm{~kg} \text { milk-based formula per week) was associated with } 3.4 \\
\text { unit }(95 \% \text { CI: } 0.5,6.3) \text { increase in DQ from enrollment to } 12 \text { months and } 6.1 \\
\text { units }(95 \% \text { CI: } 2.9,9.4) \text { increase in DQ from enrollment to } 24 \text { months. }\end{array}$ & $\begin{array}{l}9-24 \\
\text { months }\end{array}$ & 2 years & Griffith's Mental development Scale \\
\hline $\begin{array}{l}\text { (Grantham- } \\
\text { McGregor et } \\
\text { al., 1996) }\end{array}$ & Jamaica & $\begin{array}{l}\text { Supplementation }(1 \mathrm{~kg} \text { of full cream milk per week), conditional on height } \\
\text { gain in the first year, was associated with } 1.91 \text { unit increase in DQ }(\mathrm{p}<0.01) \\
\text { and significantly affected change in mental age }(\mathrm{p}<0.001) \text {. }\end{array}$ & $\begin{array}{l}9-24 \\
\text { months }\end{array}$ & $2-4$ years & $\begin{array}{l}\text { Mental age, Development Quotient } \\
\text { (DQ) }\end{array}$ \\
\hline $\begin{array}{l}\text { (Grantham- } \\
\text { McGregor et } \\
\text { al., 1997) }\end{array}$ & Jamaica & $\begin{array}{l}\text { Four years after the end of the two-year supplementation intervention }(1 \mathrm{~kg} \\
\text { milk-based formula per week), there was only a very small global benefit of } \\
\text { supplementation detected. }\end{array}$ & $\begin{array}{l}9-24 \\
\text { months }\end{array}$ & $7-8$ years & $\begin{array}{l}\text { WRAT, Stanford Binet, PPVT, RPM, } \\
\text { Categorical fluency, Verbal analogies, } \\
\text { Free recall, French learning test, Digit } \\
\text { span, Corsi blocks. Lafayette Grooved } \\
\text { Pegboard Test }\end{array}$ \\
\hline $\begin{array}{l}\text { (Walker, } \\
\text { 2006) }\end{array}$ & Jamaica & $\begin{array}{l}\text { Sixteen years after the end of the two-year supplementation intervention }(1 \mathrm{~kg} \\
\text { milk-based formula per week), there was no significant effect on cognitive } \\
\text { development outcomes. }\end{array}$ & $\begin{array}{l}9-24 \\
\text { months }\end{array}$ & $17-18$ years & $\begin{array}{l}\text { WAIS, RPM, Corsi Blocks, Auditory } \\
\text { working memory, PPVT, verbal } \\
\text { analogies, reading tests, WRAT, school } \\
\text { drop out }\end{array}$ \\
\hline $\begin{array}{l}\text { (Waber et al., } \\
\text { 1981) }\end{array}$ & Colombia & $\begin{array}{l}\text { Nutritional supplementation increased locomotor, personal-social, speech and } \\
\text { language, hand-eye coordination, and performance skills as well as general } \\
\text { IQ. }\end{array}$ & $\begin{array}{l}\text { 3rd } \\
\text { trimester- } \\
\text { 3years }\end{array}$ & $\begin{array}{l}4-36 \\
\text { months }\end{array}$ & $\begin{array}{l}\text { Griffith's Mental Development Tests, } \\
\text { Corman-Escalona Einstein scale }\end{array}$ \\
\hline $\begin{array}{l}\text { (Pollitt et al., } \\
\text { 1997) }\end{array}$ & Indonesia & $\begin{array}{l}\text { Children who received three-month supplementation in the first } 18 \text { months } \\
\text { performed better on working memory tests, but other cognitive outcomes were } \\
\text { not significantly different from the control groups. }\end{array}$ & $\begin{array}{l}6-60 \\
\text { months }\end{array}$ & 8 years & $\begin{array}{l}\text { PPVT, information processing, word } \\
\text { fluency, arithmetic test, working } \\
\text { memory }\end{array}$ \\
\hline $\begin{array}{l}\text { (Pollitt et al., } \\
\text { 1993) }\end{array}$ & Guatemala & $\begin{array}{l}\text { Children who received Atole supplement had } 4.58 \text { higher scores on the motor } \\
\text { component of the Composite Infant Scale at } 24 \text { months of age }(\mathrm{p}<0.001) \text {. } \\
\text { They also had higher scores on the preschool battery between } 4-5 \text { years. }\end{array}$ & $\begin{array}{l}\text { In utero to } \\
3 \text { years }\end{array}$ & $2-6$ years & $\begin{array}{l}\text { Brazelton Neonatal Assessment, } \\
\text { Composite Infant Scale and Preschool } \\
\text { Battery }\end{array}$ \\
\hline $\begin{array}{l}\text { (Pollitt et al., } \\
\text { 1995) }\end{array}$ & Guatemala & $\begin{array}{l}\text { Children who received Atole supplement had: (1) Vocabulary: } 22.35 \\
(\mathrm{p}<0.001) \text {; (2) Numeracy: } 7.75(\mathrm{p}<0.01) ;(3) 8.57(\mathrm{p}<0.01) \text {; and (4) } 20.05 \\
(\mathrm{p}<0.001) \text { higher scores. }\end{array}$ & $\begin{array}{l}\text { In utero to } \\
3 \text { years }\end{array}$ & $13-19$ years & $\begin{array}{l}\text { Age of starting school, highest grade in } \\
\text { primary school, tests of numeracy, } \\
\text { literacy, general knowledge, two } \\
\text { standardized educational achievement } \\
\text { tests, RPM, tests of information } \\
\text { processing }\end{array}$ \\
\hline
\end{tabular}

Abbreviations: BSID: Bayley Scales of Infant Development ( $2^{\text {nd }}$ version). CAT: Cognitive Abilities Test. HAZ: height for age z-score. CI: confidence interval. DQ: Development quotient. IQ: Intelligence

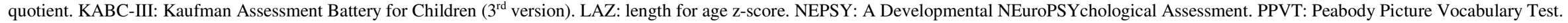

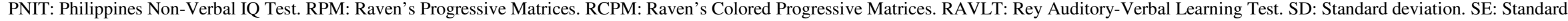

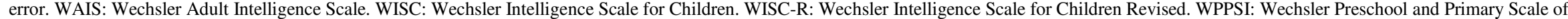
Intelligence. WRAT: Wide Range Achievement Test. 


\section{Web Table 9. Synergistic Nutrition + Psychosocial Intervention Studies on Stunting and Child Development}

\begin{tabular}{|c|c|c|c|c|c|}
\hline Citation & Country & Findings & $\begin{array}{l}\text { Age of } \\
\text { enrollment }\end{array}$ & $\begin{array}{l}\text { Age of } \\
\text { assessment }\end{array}$ & Development measures \\
\hline $\begin{array}{l}\text { (Susan M } \\
\text { Chang et al., } \\
\text { 2010) }\end{array}$ & Jamaica & $\begin{array}{l}\text { No significant interaction between the two interventions was observed for fine } \\
\text { motor skills (effect sizes in SDs: } 0.08 \text { for RSCM and } 0.04 \text { for dexterity). }\end{array}$ & 9-24 months & $11-12$ years & $\begin{array}{l}\text { Grooved Pegboard, Bruininks- } \\
\text { Oseretsky Test of Motor } \\
\text { Proficiency, Neurological } \\
\text { Examination of Soft Signs, Finger } \\
\text { tap }\end{array}$ \\
\hline $\begin{array}{l}\text { (Nahar et al., } \\
\text { 2012) }\end{array}$ & Bangladesh & $\begin{array}{l}\text { - The combined intervention group had higher MDI compared to hospital control } \\
\text { (mean difference }=4.5 ; \mathrm{p}=0.022 \text { ) and clinic control groups }(3.4 ; \mathrm{p}=0.092) \text {. } \\
\text { - The combined intervention group had higher PDI compared to hospital control } \\
\text { (mean difference }=4.8 ; \mathrm{p}=0.031 \text { ), clinic control groups }(4.6 ; \mathrm{p}=0.047) \text { and food } \\
\text { supplementation only group }(6.3 ; \mathrm{p}=0.003 \text { ). } \\
\text { - The combined intervention group had a } 0.3 \text { unit higher WAZ }(\mathrm{p}=0.011 \text { ) and LAZ } \\
(\mathrm{p}=0.048 \text { ) compared with hospital control group. }\end{array}$ & 6-24 months & 9-30 months & BSID-II (PDI) \\
\hline $\begin{array}{l}\text { (Grantham- } \\
\text { McGregor et al., } \\
\text { 1991) }\end{array}$ & Jamaica & $\begin{array}{l}\text { The treatment effects were additive, and combined interventions were significantly } \\
\text { more effective than either alone. } \\
\text { - The combined intervention group had } 13.4(95 \% \text { CI: } 8.8,17.9) \text { increase in DQ } \\
\text { compared to the control group; } 5.5 \text { ( } 95 \% \text { CI: } 0.8,10.2) \text { increase compared to } \\
\text { stimulation only group; and } 6.9 \text { ( } 95 \% \text { CI: } 2.3,11.4) \text { increase compared to } \\
\text { supplementation only group. } \\
\text { - The combined intervention group had } 21.3(95 \% \text { CI: } 11.9,30.7) \text { increase in } \\
\text { locomotor skills compared to the control group; } 9.6(95 \% \text { CI: } 0.1,19.3) \text { increase } \\
\text { compared to stimulation only group; and } 9.0 \text { (95\% CI: } 0.4,18.5) \text { increase } \\
\text { compared to supplementation only group. }\end{array}$ & 9-24 months & $\begin{array}{l}12 \text { months, } 24 \\
\text { months }\end{array}$ & $\begin{array}{l}\text { Griffith's Mental development } \\
\text { Scale }\end{array}$ \\
\hline $\begin{array}{l}\text { (Grantham- } \\
\text { McGregor et al., } \\
\text { 1997) }\end{array}$ & Jamaica & $\begin{array}{l}\text { Four years after the end of the two-year program, there was no longer an additive } \\
\text { effect of combined treatments. }\end{array}$ & 9-24 months & $7-8$ years & $\begin{array}{l}\text { Digit span, Corsi blocks. } \\
\text { Lafayette Grooved Pegboard Test }\end{array}$ \\
\hline $\begin{array}{l}\text { (Walker et al., } \\
\text { 2007) }\end{array}$ & Jamaica & $\begin{array}{l}\text { Stimulation, but not supplementation, had significant benefits on psychological } \\
\text { functioning. Hence, the supplement only group was combined with the control } \\
\text { group. }\end{array}$ & 9-24 months & $17-18$ years & $\begin{array}{l}\text { How I Think About Myself } \\
\text { Questionnaire, Manifest Anxiety } \\
\text { Questionnaire, Short Mood and } \\
\text { Feelings Questionnaire, Behavior } \\
\text { and Activities Checklist, Conners' } \\
\text { Parent Rating Scale }\end{array}$ \\
\hline $\begin{array}{l}\text { (Meeks Gardner } \\
\text { et al., 1999) }\end{array}$ & Jamaica & $\begin{array}{l}\text { The presence of intervention was not significant in either set of analyses. Hence } \\
\text { the supplement only group, stimulation only group, and combined intervention } \\
\text { group was grouped into a single stunted group. }\end{array}$ & $\begin{array}{l}12-24 \\
\text { months }\end{array}$ & 18-30 months & $\begin{array}{l}\text { Griffiths' Mental Development } \\
\text { Scales }\end{array}$ \\
\hline
\end{tabular}




\section{References}

Aboud, F.E., Akhter, S., 2011. A cluster-randomized evaluation of a responsive stimulation and feeding intervention in Bangladesh. Pediatrics 127, e1191ee1197.

Aboud, F.E., Yousafzai, A.K., 2015. Global health and development in early childhood. Annu. Rev. Psychol. 66, 433 e457.

Abubakar, A., Van de Vijver, F., Van Baar, A., Mbonani, L., Kalu, R., Newton, C., et al., 2008. Socioeconomic status, anthropometric status, and psychomotor development of Kenyan children from resource-limited settings: a path-analytic study. Early Hum. Dev. 84, 613e621.

Adair, L.S., Fall, C.H.D., Osmond, C., Stein, A.D., Martorell, R., Ramirez-Zea, M., et al., 2013. Associations of linear growth and relative weight gain during early life with adult health and human capital in countries of low and middle income: findings from five birth cohort studies. Lancet $382,525 \mathrm{e} 534$.

Adolph, K.E., Vereijken, B., Shrout, P.E., 2003. What changes in infant walking and why. Child. Dev. 74, 475e497.

Alberto Camargo-Figuera, F., Barros, A.J.D., Santos, I.S., Matijasevich, A., Barros, F.C., 2014. Early life determinants of low IQ at age 6 in children from the 2004 Pelotas Birth Cohort: a predictive approach. BMC Pediatr. 14, 308.

Alderman, H., Behrman, J.R., Grantham-McGregor, S., Lopez-Boo, F., Urzua, S., 2014. Economic perspectives on integrating early child stimulation with nutritional interventions. Ann. N. Y. Acad. Sci. 1308, 129e138.

Aubuchon-Endsley, N.L., Grant, S.L., Berhanu, G., Thomas, D.G., Schrader, S.E., Eldridge, D., et al., 2011. Hemoglobin, growth, and attention of infants in southern Ethiopia. Child. Dev. 82, 1238 .

Aurino, E., Burchi, F., 2014. Children's Multidimensional Health and Medium-run Cognitive Skills in Low-and Middle-income Countries. Young Lives Working Paper.

Avan, B., Richter, L.M., Ramchandani, P.G., Norris, S.A., Stein, A., 2010. Maternal postnatal depression and children's growth and behaviour during the early years of life: exploring the interaction between physical and mental health. Arch. Dis. Child. 95, 690e695.

Barnett, I., Ariana, P., Petrou, S., Penny, M.E., Duc, L.T., Galab, S., et al., 2013. Cohort profile: the Young Lives study. Int. J. Epidemiol. 42, 701e708.

Behrman, J.R., Birdsall, N., 1983. The quality of schooling: quantity alone is misleading. Am. Econ. Rev. 73, 928e946.

Berger, A., 2001. Insulin-like growth factor and cognitive function. BMJ 322, 203e203. 
Berkman, D.S., Lescano, A.G., Gilman, R.H., Lopez, S.L., Black, M.M., 2002. Effects of stunting, diarrhoeal disease, and parasitic infection during infancy on cognition in late childhood: a followup study. Lancet 359, 564e571.

Black, M.M., 1998. Zinc deficiency and child development. Am. J. Clin. Nutr. 68, 464Se469S.

Black, M.M., Perez-Escamilla, R., Fernandez-Rao, S., 2015. Integrating nutrition and child development interventions: scientific basis, evidence of impact, and implementation considerations. Adv. Nutr. An Int. Rev. J. 6, 852e859.

Black, M.M., Walker, S.P., Fernald, L.C.H., Andersen, C.T., DiGirolamo, A.M., Lu, C., et al., 2016. Early childhood development coming of age: science through the life course. Lancet 389, $77 \mathrm{e} 90$.

Black, R.E., Victora, C.G., Walker, S.P., Bhutta, Z.A., Christian, P., De Onis, M., et al., 2013. Maternal and child undernutrition and overweight in low-income and middle-income countries. Lancet 382, 427e451.

Bogale, A., Stoecker, B.J., Kennedy, T., Hubbs-Tait, L., Thomas, D., Abebe, Y., et al., 2013. Nutritional status and cognitive performance of mother-child pairs in Sidama, Southern Ethiopia. Matern. Child Nutr. 9, 274e284.

Britto, P.R., Lye, S.J., Proulx, K., Yousafzai, A.K., Matthews, S.G., Vaivada, T., et al., 2016. Nurturing care: promoting early childhood development. Lancet 389, 91e102.

Casale, D., Desmond, C., Richter, L., 2014. The association between stunting and psychosocial development among preschool children: a study using the South African Birth to Twenty cohort data. Child care, health Dev. 40, 900e910.

Chang, S.M., Walker, S.P., Grantham-McGregor, S., Powell, C.A., 2002. Early childhood stunting and later behaviour and school achievement. J. Child Psychol. Psychiatry, Allied Discip. 43, $775 \mathrm{e} 783$.

Chang, S.M., Walker, S.P., Grantham-McGregor, S., Powell, C.A., 2010. Early childhood stunting and later fine motor abilities. Dev. Med. Child Neurol. 52, 831e836.

Cheung, Y.B., Ashorn, P., 2010. Continuation of linear growth failure and its association with cognitive ability are not dependent on initial length-for-age: a longitudinal study from 6 months to 11 years of age. Acta Paediatr. 99, 1719e1723.

Cheung, Y.B., Gladstone, M., Maleta, K., Duan, X., Ashorn, P., 2008. Comparison of four statistical approaches to score child development: a study of Malawian children. Trop. Med. Int. Health 13, 987e993. 
Cheung, Y.B., Yip, P., Karlberg, J., 2001. Fetal growth, early postnatal growth and motor development in Pakistani infants. Int. J. Epidemiol. 30, 66e 72.

Christian, P., Mullany, L.C., Hurley, K.M., Katz, J., 2015. Nutrition and maternal, neonatal, and child health. Semin. Perinatol. 39, 361e371.

Corsi, D.J., Perkins, J.M., Subramanian, S.V., 2017. Child anthropometry data quality from demographic and health Surveys, multiple indicator cluster Surveys, and national nutrition Surveys in the west central africa region: are we comparing apples and oranges? Glob. Health Action 10, 1328185 .

Crookston, B.T., Dearden, K.A., Alder, S.C., Merrill, R.M., Dickerson, T.T., Stanford, J.B., et al., 2010a. Peruvian children who recover from early stunting and well nourished children demonstrate similar cognition. FASEB J. 24, 734e736.

Crookston, B.T., Dearden, K.A., Alder, S.C., Porucznik, C.A., Stanford, J.B., Merrill, R.M., et al., 2011. Impact of early and concurrent stunting on cognition. Matern. Child Nutr. 7, 397 e409.

Crookston, B.T., Penny, M.E., Alder, S.C., Dickerson, T.T., Merrill, R.M., Stanford, J.B., et al., 2010b. Children who recover from early stunting and children who are not stunted demonstrate similar levels of cognition. J. Nutr. 140, 1996e2001.

Crookston, B.T., Schott, W., Cueto, S., Dearden, K.A., Engle, P., Georgiadis, A., et al., 2013. Postinfancy growth, schooling, and cognitive achievement: Young Lives. Am. J. Clin. Nutr. 98, $1555 \mathrm{e} 1563$.

Currie, J., Vogl, T., 2013. Early-life health and adult circumstance in developing countries. Annu. Rev. Econ. 5, 1e36.

Dercon, S., Porter, C., 2014. Live aid revisited: long-term impacts of the 1984 Ethiopian famine on children. J. Eur. Econ. Assoc. 12, 927e948.

DiGirolamo, A.M., Stansbery, P., Lung'aho, M., 2014. Advantages and challenges of integration: opportunities for integrating early childhood development and nutrition programming. Ann. N. Y. Acad. Sci. 1308, 46e53.

Dua, T., Tomlinson, M., Tablante, E., Britto, P., Yousfzai, A., Daelmans, B., et al., 2016. Global research priorities to accelerate early child development in the sustainable development era. Lancet Glob. Health 4, e887ee889.

Fernald, L., Gertler, P.J., Neufeld, L.M., 2008. Role of cash in conditional cash transfer programmes for child health, growth, and development: an analysis of Mexico's Oportunidades. Lancet $371,828 \mathrm{e} 837$. 
Fernald, L., Gertler, P.J., Neufeld, L.M., 2009a. 10-year effect of Oportunidades, Mexico's conditional cash transfer programme, on child growth, cognition, language, and behaviour: a longitudinal follow-up study. Lancet 374, 1997e2005.

Fernald, L., Grantham-McGregor, S.M., 1998. Stress response in school-age children who have been growth retarded since early childhood. Am. J. Clin. Nutr. 68,691e698.

Fernald, L., Hidrobo, M., 2011. Effect of Ecuador's cash transfer program (Bono de Desarrollo Humano) on child development in infants and toddlers: a randomized effectiveness trial. Soc. Sci. Med. 72, 1437e1446.

Fernald, L., Kariger, P., Engle, P.L., Raikes, A., 2009b. Examining Early Child Development in Low-income Countries. World Bank, Washington, DC.

Fernald, L., Neufeld, L.M., Barton, L.R., Schnaas, L., Rivera, J., Gertler, P.J., 2006. Parallel deficits in linear growth and mental development in low-income Mexican infants in the second year of life. Public Health Nutr. 9, 178e186.

Fernandez-Rao, S., Hurley, K.M., Nair, K.M., Balakrishna, N., Radhakrishna, K.V., Ravinder, P., et al., 2013. Integrating nutrition and early child-development interventions among infants and preschoolers in rural India. Ann. N. Y. Acad. Sci. 1308, $218 \mathrm{e} 231$.

Frongillo, E.A., Nguyen, P.H., Saha, K.K., Sanghvi, T., Afsana, K., Haque, R., et al., 2017. LargeScale behavior-change initiative for infant and young child feeding advanced language and motor development in a cluster-randomized program evaluation in Bangladesh. J. Nutr. 147, $256 \mathrm{e} 263$.

Frongillo, E.A., Tofail, F., Hamadani, J.D., Warren, A.M., Mehrin, S.F., 2014. Measures and indicators for assessing impact of interventions integrating nutrition, health, and early childhood development. Ann. N. Y. Acad. Sci. 1308, $68 \mathrm{e} 88$.

Gandhi, M., Ashorn, P., Maleta, K., Teivaanmaki, T., Duan, X., Cheung, Y.B., 2011. Height gain during early childhood is an important predictor of schooling and mathematics ability outcomes. Acta Paediatr. 100, 1113e1118.

Gardner, J.M., Grantham-McGregor, S.M., Chang, S.M., Himes, J.H., Powell, C.A., 1995. Activity and behavioral development in stunted and non-stunted children and response to nutritional supplementation. Child. Dev. 66, 1785e1797.

Gardner, J.M., Grantham-McGregor, S.M., Himes, J., Chang, S., 1999. Behaviour and development of stunted and non-stunted Jamaican children. J. Child Psychol. Psychiatry, Allied Discip. 40, 819e827.

Gardner, J.M.M., Powell, C.A., Baker-Henningham, H., Walker, S.P., Cole, T.J., GranthamMcGregor, S.M., 2005. Zinc supplementation and psychosocial stimulation: effects on the development of undernourished Jamaican children. Am. J. Clin. Nutr. 82, 399e405. 
Georgiadis, A., Benny, L., Duc, L.T., Galab, S., Reddy, P., Woldehanna, T., 2017. Growth recovery and faltering through early adolescence in low- and middle-income countries: determinants and implications for cognitive development. Soc. Sci. Med. 179, 81e90.

Glewwe, P., Jacoby, H.G., King, E.M., 2001. Early childhood nutrition and academic achievement: a longitudinal analysis. J. Public Econ. 81, 345e368.

Glewwe, P., King, E.M., 2001. The impact of early childhood nutritional status on cognitive development: does the timing of malnutrition matter? World Bank Econ. Rev. 15, 81e113.

Grantham-McGregor, S.M., 1984. Chronic undernutrition and cognitive abilities. Hum. Nutr. Clin. Nutr. 38, 83e94.

Grantham-McGregor, S.M., 1993. Assessments of the effects of nutrition on mental development and behavior in Jamaican studies. Am. J. Clin. Nutr. 57, 303Se309S.

Grantham-McGregor, S.M., 1995. A review of studies of the effect of severe malnutrition on mental development. J. Nutr. 125, 2233Se2238S.

Grantham-McGregor, S.M., Baker-Henningham, H., 2005. Review of the evidence linking protein and energy to mental development. Public Health Nutr. 8, 1191e1201.

Grantham-McGregor, S.M., Cheung, Y.B., Cueto, S., Glewwe, P., Richter, L., Strupp, B., 2007. Developmental potential in the first 5 years for children in developing countries. Lancet 369, $60 \mathrm{e} 70$.

Grantham-McGregor, S.M., Fernald, L.C.H., Kagawa, R.M.C., Walker, S., 2014. Effects of integrated child development and nutrition interventions on child development and nutritional status. Ann. N. Y. Acad. Sci. 1308, 11e32.

Grantham-McGregor, S.M., Powell, C.A., Walker, S.P., Himes, J.H., 1991. Nutritional supplementation, psychosocial stimulation, and mental development of stunted children: the Jamaican Study. Lancet 338, 1e5.

Grantham-McGregor, S.M., Walker, S.P., Chang, S.M., Powell, C.A., 1997. Effects of early childhood supplementation with and without stimulation on later development in stunted Jamaican children. Am. J. Clin. Nutr. 66, 247e253.

Grantham-McGregor, S.M., Walker, S.P., Himes, J.H., Powell, C.A., 1996. Stunting and mental development in children. Nutr. Res. 16, 1821e1828.

Hamadani, J.D., Tofail, F., Cole, T., Grantham-McGregor, S., 2012. The relation between age of attainment of motor milestones and future cognitive and motor development in Bangladeshi children. Matern. Child Nutr. 9, 89e104. 
Hamadani, J.D., Tofail, F., Huda, S.N., Alam, D.S., Ridout, D.A., Attanasio, O., et al., 2014. Cognitive deficit and poverty in the first 5 years of childhood in Bangladesh. Pediatrics 134, e1001ee1008.

Handal, A.J., Lozoff, B., Breilh, J., Harlow, S.D., 2007. Sociodemographic and nutritional correlates of neurobehavioral development: a study of young children in a rural region of Ecuador. Rev. Panam. Salud Pública 21, 292e300.

Hurley, K.M., Yousafzai, A.K., Lopez-Boo, F., 2016. Early child development and nutrition: a review of the benefits and challenges of implementing integrated interventions. Adv. Nutr. 7, $357 \mathrm{e} 363$.

Ioannidis, J.P.A., 2016. The mass production of redundant, misleading, and conflicted systematic reviews and meta-analyses. Milbank Q. 94, 485e514.

Isaacs, E., Oates, J., 2008. Nutrition and cognition: assessing cognitive abilities in children and young people. Eur. J. Nutr. 47, 4e24.

John, C.C., Black, M.M., Nelson, C.A., 2017. Neurodevelopment: the impact of nutrition and inflammation during early to middle childhood in low-resource settings. Pediatrics 139, S59eS71.

Kariger, P.K., Stoltzfus, R.J., Olney, D., Sazawal, S., Black, R., Tielsch, J.M., et al., 2005. Iron deficiency and physical growth predict attainment of walking but not crawling in poorly nourished Zanzibari infants. J. Nutr. 135, 814e819.

Ketema, L., Abate, G., Jabar, M., 2003. Correlates of children's cognitive skills in an Agrarian community with mixed crop-livestock production systems, Ghinchi, central Ethiopia. Ethiop. Med. J. 41, 151e161.

Khan, M.A., Owais, S.S., Blacklock, C., Anil, S., Ishaq, S., Maqbool, S., et al., 2017. Delivering integrated child development care in Pakistan: protocol for a clustered randomised trial. BJGP Open 1.

Kordas, K., Lopez, P., Rosado, J.L., Garcia Vargas, G., Alatorre Rico, J., Ronquillo, D., et al., 2004. Blood lead, anemia, and short stature are independently associated with cognitive performance in Mexican school children. J. Nutr. 134, 363e371.

Kuklina, E.V., Ramakrishnan, U., Stein, A.D., Barnhart, H.H., Martorell, R., 2004. Growth and diet quality are associated with the attainment of walking in rural Guatemalan infants. J. Nutr. 134, $3296 \mathrm{e} 3300$.

Kuklina, E.V., Ramakrishnan, U., Stein, A.D., Barnhart, H.H., Martorell, R., 2006. Early childhood growth and development in rural Guatemala. Early Hum. Dev. 82, 425e433. 
Larson, L.M., Yousafzai, A.K., 2017. A meta-analysis of nutrition interventions on mental development of children under-two in low- and middle-income countries. Matern. Child Nutr. 13, e12229.

Le Roith, D., 1997. Insulin-Like growth factors. N. Engl. J. Med. 336, 633e640.

Leight, J., Glewwe, P., Park, A., 2015. The Impact of Early Childhood Rainfall Shocks on the Evolution of Cognitive and Non-cognitive Skills.

Levitsky, D.A., Strupp, B.J., 1995. Malnutrition and the brain: changing concepts, changing concerns. J. Nutr. 125, 2212Se2220S.

Lima, M.C., Eickmann, S.H., Lima, A.C.V., Guerra, M.Q., Lira, P.I.C., Huttly, S.R.A., et al., 2004. Determinants of mental and motor development at 12 months in a low income population: a cohort study in northeast Brazil. Acta Paediatr. 93, 969e975.

Lozoff, B., 2007. Iron deficiency and child development. Food Nutr. Bull. 28, S560eS571.

Lundeen, E.A., Behrman, J.R., Crookston, B.T., Dearden, K.A., Engle, P., Georgiadis, A., et al., 2013. Growth faltering and recovery in children aged 1e8 years in four low-and middle-income countries: Young Lives. Public Health Nutr. 1 e7.

Macours, K., Schady, N., Vakis, R., 2012. Cash transfers, behavioral changes, and cognitive development in early childhood: evidence from a randomized experiment. Am. Econ. J. Appl. Econ. 4, 247e273.

Martorell, R., 1995. Results and implications of the INCAP follow-up study. J. Nutr. 125, $1127 \mathrm{Se} 1138 \mathrm{~S}$.

Mendez, M.A., Adair, L.S., 1999. Severity and timing of stunting in the first two years of life affect performance on cognitive tests in late childhood. J. Nutr. 129, 1555e1562.

Miller, A.C., Murray, M.B., Thomson, D.R., Arbour, M.C., 2015. How consistent are associations between stunting and child development? Evidence from a meta-analysis of associations between stunting and multidimensional child development in fifteen low- and middle-income countries. Public Health Nutr. 19, 1339e1347.

Mohd Nasir, M.T., Norimah, A.K., Hazizi, A.S., Nurliyana, A.R., Loh, S.H., Suraya, I., 2012. Child feeding practices, food habits, anthropometric indicators and cognitive performance among preschoolers in Peninsular Malaysia. Appetite 58, 525e530.

Murray-Kolb, L.E., Rasmussen, Z.A., Scharf, R.J., Rasheed, M.A., Svensen, E., Seidman, J.C., et al., 2014. The MAL-ED Cohort Study: methods and lessons learned when assessing early child development and caregiving mediators in infants and young children in 8 low- and middle-income countries. Clin. Infect. Dis. 59, S261eS272. 
Nahar, B., Hossain, M.I., Hamadani, J.D., Ahmed, T., Huda, S.N., Grantham-McGregor, S.M., et al., 2012. Effects of a community-based approach of food and psychosocial stimulation on growth and development of severely malnourished children in Bangladesh: a randomised trial. Eur. J. Clin. Nutr. 66, $701 \mathrm{e} 709$.

Nguyen, P.H., DiGirolamo, A.M., Gonzalez-Casanova, I., Young, M., Kim, N., Nguyen, S., et al., 2017. Influences of early child nutritional status and home learning environment on child development in Vietnam. Matern. Child Nutr.

Niehaus, M.D., Moore, S.R., Patrick, P.D., Derr, L.L., Lorntz, B., Lima, A.A., et al., 2002. Early childhood diarrhea is associated with diminished cognitive function 4 to 7 years later in children in a northeast Brazilian shantytown. Am. J. Trop. Med. Hyg. 66, 590e593.

Olney, D.K., Kariger, P.K., Stoltzfus, R.J., Khalfan, S.S., Ali, N.S., Tielsch, J.M., et al., 2009. Development of nutritionally at-risk young children is predicted by malaria, anemia, and stunting in Pemba, Zanzibar. J. Nutr. 139, 763 e772.

Olney, D.K., Pollitt, E., Kariger, P.K., Khalfan, S.S., Ali, N.S., Tielsch, J.M., et al., 2007. Young Zanzibari children with iron deficiency, iron deficiency anemia, stunting, or malaria have lower motor activity scores and spend less time in locomotion. J. Nutr. 137, $2756 \mathrm{e} 2762$.

Outes-Leon, I., Porter, C., Sanchez, A., 2011. Early Nutrition and Cognition in Peru: a Withinsibling Investigation. Inter-American Development Bank.

Paxson, C., Schady, N., 2010. Does money matter? The effects of cash transfers on child development in rural Ecuador. Econ. Dev. Cult. Change 59, 187e229.

Perez-Escamilla, R., Moran, V.H., 2017. The role of nutrition in integrated early child development in the 21st century: contribution from the Maternal and Child Nutrition journal. Matern. Child Nutr. 13, 3e6.

Perkins, J.M., Subramanian, S.V., Davey-Smith, G., €Ozaltin, E., 2016. Adult height, nutrition, and population health. Nutr. Rev. 74, 149e165.

Pollitt, E., 2000. Developmental sequel from early nutritional deficiencies: conclusive and probability judgements. J. Nutr. 130, 350Se353S.

Pollitt, E., 2009. Timing and vulnerability in research on malnutrition and cognition. Nutr. Rev. 54, S49eS55.

Pollitt, E., Gorman, K.S., Engle, P.L., Martorell, R., Rivera, J., Wachs, T.D., et al., 1993. Early supplementary feeding and cognition: effects over two decades. Monogr. Soc. Res. Child Dev. 58, 1-99- discussion 111e118.

Pollitt, E., Gorman, K.S., Engle, P.L., Rivera, J.A., Martorell, R., 1995. Nutrition in early life and the fulfillment of intellectual potential. J. Nutr. 125, 1111Se1118S. 
Pollitt, E., Watkins, W.E., Husaini, M.A., 1997. Three-month nutritional supplementation in Indonesian infants and toddlers benefits memory function 8 y later. Am. J. Clin. Nutr. 66, $1357 \mathrm{e} 1363$.

Pongcharoen, T., Ramakrishnan, U., DiGirolamo, A.M., Winichagoon, P., Flores, R., Singkhornard, J., et al., 2012. Influence of prenatal and postnatal growth on intellectual functioning in school-aged children. Arch. Pediatr. Adolesc. Med. 166, 411e416.

Prado, E.L., Abbeddou, S., Yakes Jimenez, E., Some, J.W., Dewey, K.G., Brown, K.H., et al., 2017. Effects of an intervention on infant growth and development: evidence for different mechanisms at work. Matern. Child Nutr. 13.

Prado, E.L., Dewey, K.G., 2014. Nutrition and brain development in early life. Nutr. Rev. 72, $267 \mathrm{e} 284$.

Prentice, A.M.,Ward, K.A., Goldberg, G.R., Jarjou, L.M., Moore, S.E., Fulford, A.J., et al., 2013. Critical windows for nutritional interventions against stunting. Am. J. Clin. Nutr. 97, $911 \mathrm{e} 918$.

Richter, L.M., Daelmans, B., Lombardi, J., Heymann, J., Boo, F.L., Behrman, J.R., et al., 2016. Investing in the foundation of sustainable development: pathways to scale up for early childhood development. Lancet 389, 103e118.

Richter, L.M., Victora, C.G., Hallal, P.C., Adair, L.S., Bhargava, S.K., Fall, C.H., et al., 2012. Cohort profile: the consortium of health-orientated research in transitioning societies. Int. J. Epidemiol. 41, 621e626.

Sabanathan, S., Wills, B., Gladstone, M., 2015. Child development assessment tools in lowincome and middle-income countries: how can we use them more appropriately? Arch. Dis. Child. $100,482 \mathrm{e} 488$.

Sanchez, A., 2013. The Structural Relationship between Nutrition, Cognitive and Non-cognitive Skills. Young Lives Working Paper. Young Lives.

Siegel, E.H., Stoltzfus, R.J., Kariger, P.K., Katz, J., Khatry, S.K., LeClerq, S.C., et al., 2005. Growth indices, anemia, and diet independently predict motor milestone acquisition of infants in South Central Nepal. J. Nutr. 135, $2840 \mathrm{e} 2844$.

Soeters, P.B., Schols, A.M., 2009. Advances in understanding and assessing malnutrition. Curr. Opin. Clin. Nutr. Metabol. Care 12, 487e494.

Sokolovic, N., Selvam, S., Srinivasan, K., Thankachan, P., Kurpad, A.V., Thomas, T., 2014. Catch-up growth does not associate with cognitive development in Indian school-age children. Eur. J. Clin. Nutr. 68, 14e18. 
Strupp, B.J., Levitsky, D.A., 1995. Enduring cognitive effects of early malnutrition: a theoretical reappraisal. J. Nutr. 125, 2221Se2232S.

Sudfeld, C.R., Charles McCoy, D., Danaei, G., Fink, G., Ezzati, M., Andrews, K.G., et al., 2015. Linear growth and child development in low- and middle-income vountries: a meta-analysis. Pediatrics 135, e1266ee1275.

Taneja, S., Bhandari, N., Bahl, R., Bhan, M.K., 2005. Impact of zinc supplementation on mental and psychomotor scores of children aged 12 to 18 months: a randomized, double-blind trial. J. Pediatr. 146, 506e511.

Teivaanmaki, T., Bun Cheung, Y., Pulakka, A., Virkkala, J., Maleta, K., Ashorn, P., 2017. Height gain after two-years-of-age is associated with better cognitive capacity, measured with Raven's coloured matrices at 15-years-of-age in Malawi. Matern. Child Nutr. 13 e12326.

Thompson, R.A., Nelson, C.A., 2001. Developmental science and the media: early brain development. Am. Psychol. 56, 5e15.

Umana-Aponte, M., 2011. Long-term Effects of a Nutritional Shock: the 1980 Famine of Karamoja, Uganda. Center for Market and Public Organisation (Working Paper).

UN, 2015. Sustainable Development Goals. United Nations.

UNICEF, 2013. Improving Child Nutrition: the Achievable Imperative for Global Progress. UNICEF, New York, NY.

UNICEF, WHO, WB, 2016. Levels and Trends in Malnutrition. UNICEF/WHO/World Bank Group Joint Child Malnutrition Estimates: Key Findings of the 2016 Edition.

van Pareren, Y.K., Duivenvoorden, H.J., Slijper, F.S.M., Koot, H.M., Hokken- Koelega, A.C.S., 2004. Intelligence and psychosocial functioning during long=term growth hormone therapy in children born small for gestational age. J. Clin. Endocrinol. Metabol. 89, 5295e5302.

Vazir, S., Engle, P., Balakrishna, N., Griffiths, P.L., Johnson, S.L., Creed-Kanashiro, H., et al., 2012. Cluster-randomized trial on complementary and responsive feeding education to caregivers found improved dietary intake, growth and development among rural Indian toddlers. Matern. Child Nutr. 9, 99e117.

Vazir, S., Engle, P., Balakrishna, N., Griffiths, P.L., Johnson, S.L., Creed-Kanashiro, H., et al., 2013. Cluster-randomized trial on complementary and responsive feeding education to caregivers found improved dietary intake, growth and development among rural Indian toddlers. Matern. Child Nutr. 9, 99e117.

Vohr, B.R., Poggi Davis, E., Wanke, C.A., Krebs, N.F., 2017. Neurodevelopment: the impact of nutrition and inflammation during preconception and pregnancy in low-resource settings. Pediatrics 139, S38eS49. 
Waber, D.P., Vuori-Christiansen, L., Ortiz, N., Clement, J.R., Christiansen, N.E.,Mora, J.O., et al., 1981. Nutritional supplementation, maternal education, and cognitive development of infants at risk of malnutrition. Am. J. Clin. Nutr. 34, 807e813.

Wachs, T.D., Georgieff, M., Cusick, S., McEwen, B.S., 2013. Issues in the timing of integrated early interventions: contributions from nutrition, neuroscience, and psychological research. Ann. N. Y. Acad. Sci. 1308, 89e106.

Walker, S.P., 2006. Effects of psychosocial stimulation and dietary supplementation in early childhood on psychosocial functioning in late adolescence: follow-up of randomised controlled trial. BMJ 333, 472e470.

Walker, S.P., Chang, S.M., Powell, C.A., 2007a. Early childhood stunting is associated with poor psychological functioning in late adolescence and effects are reduced by psychosocial stimulation. J. Nutr. 137, 2464e2469.

Walker, S.P., Grantham-McGregor, S.M., Powell, C.A., Chang, S.M., 2000. Effects of growth restriction in early childhood on growth, IQ, and cognition at age 11 to 12 years and the benefits of nutritional supplementation and psychosocial stimulation. J. Pediatr. 137, 36e41.

Walker, S.P., Wachs, T.D., Gardner, J.M., Lozoff, B., Wasserman, G.A., Pollitt, E., et al., 2007b. Child development: risk factors for adverse outcomes in developing countries. Lancet 369, $145 \mathrm{e} 157$.

Walker, S.P., Wachs, T.D., Grantham-McGregor, S., Black, M.M., Nelson, C.A., Huffman, S.L., et al., 2011. Inequality in early childhood: risk and protective factors for early child development. Lancet 378, 1325e1338.

Whaley, S.E., Sigman, M., Espinosa, M.P., Neumann, C.G., 1998. Infant predictors of cognitive development in an undernourished Kenyan population. J. Dev. Behav. Pediatr. 19, 169 e177.

WHO, 2006. WHO Child Growth Standards: Length/height-for-age, Weight-for-age, Weight-forlength, Weight-for-height and Body Mass Index-for-age: Methods and Development. World Health Organization, Geneva.

Yang, S., Tilling, K., Martin, R., Davies, N., Ben-Shlomo, Y., Kramer, M.S., 2011. Prenatal and post-natal growth trajectories and childhood cognitive ability and mental health. Int. J. Epidemiol. $40,1215 \mathrm{e} 1226$.

Yousafzai, A.K., Aboud, F., 2014. Review of implementation processes for integrated nutrition and psychosocial stimulation interventions. Ann. N. Y. Acad. Sci. 1308, 33e45.

Yousafzai, A.K., Rasheed, M.A., Rizvi, A., Armstrong, R., Bhutta, Z.A., 2014. Effect of integrated responsive stimulation and nutrition interventions in the Lady Health Worker programme in Pakistan on child development, growth, and health outcomes: a cluster-randomised factorial effectiveness trial. Lancet 384, 1282e1293. 